\title{
The Theoretical and Empirical Fragilities of the Expansionary Austerity Theory
}

\author{
Alberto Botta \\ Daniele Tori
}

Alberto Botta, Department of International Business and Economics, University of Greenwich. Email: A.Botta@Greenwich.ac.uk.

Daniele Tori, Department of Accounting and Finance, Open University. Email: Daniele.tori@open.ac.uk.

Acknowledgments: The authors gratefully acknowledge useful comments and suggestions from anonymous referees, which helped to significantly improve this work. The usual disclaimer applies. 


\begin{abstract}
Criticism to expansionary austerity theory has extensively addressed the methodological problems affecting the econometric techniques that underpin it; however, few efforts have formally analysed its theoretical strictures. In this paper we develop a more general and comprehensive critique, both from a theoretical and from an empirical perspective. We first present a short-run model that formally describes the theoretical background of specific policy measures advocated by expansionary austerity supporters. We show how these measures might only have expansionary outcomes under extreme and unrealistic conditions. We then move to the data, and provide an econometric analysis of the key variables that leave the results of our theoretical model undetermined; our findings reinforce the validity of our theoretical critique. Since 2007, when an important opportunity to test expansionary austerity presented itself with the recession, the core mechanisms of expansionary austerity theory seem to not have been working, to say the least. In fact, austerity measures delivered perverse results precisely in the countries where they were expected to be most effective.
\end{abstract}

Keywords: Fiscal policy, expansionary austerity theory, post-Keynesian macro models JEL Classifications: E12, E61, E62. 


\section{The expansionary austerity theory and its (empirical) critiques: A brief overview}

The theory of expansionary austerity (henceforth EAT) is part of a long-standing debate in economic literature on the effectiveness of fiscal policy (with respect to monetary policy). Nonetheless, EAT as we currently know it was introduced at the beginning of the $90 \mathrm{~s}$, when some economists stated that discretionary expansionary fiscal policies might have non-Keynesian effects, since that they may prove to be ineffective in stimulating economic activity and might put the solidity of public finance and of the economy's whole financial system at risk at the same time (see Giavazzi and Pagano, 1990 and 1996; Alesina and Perotti, 1997; Alesina and Ardagna, 2010 and 2012) ${ }^{1}$. Continuing along this line of thought, these economists also argued that well-conceived fiscal restrictions might actually stimulate private consumption and investment expenditures, as well as improve export dynamics, so that the overall economic activity might eventually expand rather than contract.

The supporters of expansionary austerity stress that well-designed fiscal consolidations must take the form of deep, persistent and credible cuts to public expenditure, in particular public transfers and public employees' wages, perhaps followed by reductions in the tax burden on households (Alesina and Perotti, 1997). In their view, such a shift in fiscal policy constitutes a "regime change" that might immediately foster economic activity through three main mechanisms. First, successful fiscal corrections may positively affect the behaviour of private economic actors through the so-called "expectation channel". Upfront public spending cuts, EAT supporters argue, may induce economic agents to develop optimistic expectations by anticipating future tax reductions and consequent increases in (permanent) income. This, in turn, may incentivize them to raise consumption expenditures immediately, giving momentum to the economic activity. Second, tough fiscal corrections that prove to be effective in reducing public deficit and public debt stocks can stimulate investments and growth, by re-establishing bond vigilantes' trust in public finances' solvency and prompting a significant reduction in interest rates (i.e. the so-called "financial channel"). Last but not least, cuts in public wages that help moderate wages on the labour market may give rise to a kind of internal devaluation that might eventually improve external competitiveness and foster net exports (we will label it the "external channel").

The economic literature that supports the expansionary austerity standpoint most strongly is mainly empirical. It supports the idea that well-designed fiscal retrenchments can lead to quick economic expansions, and that this is a theoretically and conceptually universal proposition. They do this by carrying out cross-country analyses of a sample of relevant expansionary/contractionary fiscal episodes. From a technical point of view, the EAT literature generally builds its empirical tests on the concept of cyclically adjusted primary public balances (henceforth CAPB), and takes significant shifts in countries' CAPBs as signs of discretionary expansionary or restrictive fiscal policies (see Alesina and Perotti, 1997; Alesina and Ardagna, 2010, 2012).

Most of the criticisms to the EAT also rely on an empirical approach. Guajardo et al. (2011), and Baker and Rosnick (2014), for instance, stress that the concept of CAPB is not capable of completely cancelling the effects the economic cycle has on the evolution of public finances. Indeed, purely cyclical components of public balances that are positively correlated with the economic cycle are misinterpreted and wrongly held accountable for discretionary restrictive fiscal policy shocks. As a consequence, the apparent positive correlation between fiscal consolidation and economic expansion is easy to point out, but it is the outcome of a biased empirical approach and of the econometric misunderstanding of rather different economic mechanisms. Guajardo et al. (2011), and Baker and Rosnick (2014) also raise a perhaps more relevant issue of causality. Indeed, fiscal 
variables and economic growth influence each other. The causality runs both ways: fiscal policy can surely influence economic performances, positively or negatively. Economic dynamics, in turn, have clear effects on the improvement or worsening of public balances, as well as on the type of fiscal stances followed by government authorities. The results of the CAPB-based literature may thus be misleading simply because they take changes in the CAPB as an exogenous explicative variable, when it is, in fact, endogenous.

In order to address these estimation problems, Guajardo et al. (2011) suggest an alternative method to identify episodes of fiscal adjustment. When this alternative approach is applied, the authors find a clearly negative effect of budget cuts and/or tax hikes on contemporary economic activity even "in cases where one would most expect fiscal consolidation to raise private domestic demand (Guajardo et al., 2011, p.29)". In fact, "even large spending-based fiscal retrenchments are contractionary, as are fiscal consolidations occurring in economies with a high perceived sovereign default risk (Guajardo et al., 2011, p.29)".

The abovementioned findings are obviously consistent with the expanding empirical literature that has recently put forward the idea of a cycle-contingent fiscal multiplier, which may be particularly large and positive during recessions (Auerbach and Gorodnichenko, 2012; Qazizada and Stockhammer, 2015). This evidence is radically at odds with the negative fiscal multiplier implicitly advocated by the EAT.

This paper develops a perhaps more general critical analysis of the EAT with respect to the already existing - and prevalently empirical - critique. We first focus our analysis on the theory. At the best of our knowledge, only few works have tried to analytically underline the logical weaknesses of the EAT from a heterodox perspective. However, we find these contributions to be unsatisfactory, either because they rely on ad-hoc assumptions or because they describe austerity too roughly and superficially, without considering the specific policy measures composing welldesigned (supposedly expansionary) austerity packages. In this paper, we try to fill this gap by presenting a simple model that can describe the main components of a well-designed austerity package in more detail and at the same time consider the crucial mechanisms and variables of expansionary austerity theory (i.e. the expectation, financial and external channels). Our theoretical critique relies on the understanding that economic expansion is far from being an automatic and straightforward outcome of fiscal retrenchments. This holds true even when these fiscal retrenchments are properly modelled and the mechanisms through which they might boost the economy are taken into account. We show that even when we adopt an "expansionary austerity-like theoretical framework", the expansionary outcomes of austerity policies cannot be taken for granted. Therefore, the theoretical fundamentals of EAT turn out to be extremely fragile and stateor institution-contingent, to say the least. Surely they cannot be taken as well-established and universal guidelines for conducting fiscal policy.

We finally return to empirical evidence. Differently from previous analyses, we do not investigate the methodological soundness of the EAT literature. Rather, we directly test the empirical validity of the main mechanisms at the basis of EAT in a sample of developed countries. We consider both monetarily sovereign and non-monetarily sovereign countries (such as Eurozone economies) in order to check for the operativeness of EAT's mechanisms within different "monetary regimes" in which both monetary and fiscal policies are implemented. Our findings support the theoretical perplexities raised in the first part of the paper. Since 2007, expectation and external channels seem not to have played any significant role, or have been opposite to what EAT supporters would have expected. More importantly, in the context of Eurozone countries, fiscal contractions seem to have triggered a "perverse" financial channel that has led to hikes in sovereign 
bond yields and growing financial distress, rather than increasing governments' credibility and fostering optimistic feelings on financial markets. In the case of monetarily sovereign economies, our empirical findings confirm that monetary sovereignty itself has been the most important factor in creating a crisis-resilient macroeconomic environment, not austerity measures.

To conclude, we propose a comprehensive theoretical and empirical critique of the highly influential assertion by Alberto Alesina (at least for the design of austerity measures in the Eurozone), that "many even sharp reductions of budget deficits [assuming that fiscal austerity effectively contributes to lower budget deficits] have been accompanied and immediately followed by sustained growth rather than recessions even in the very short run (Alesina, 2010, p.3)”.

\section{A simple short-run model of the expansionary/contractionary effects of fiscal adjustments}

Most of the critiques to the EAT focus on the debatable economic concepts (i.e. the CAPB), and on the related econometric techniques used by EAT supporters to validate their non-Keynesian perspective on fiscal policies. To the best of our knowledge, only few non-mainstream studies have aimed at showing the intrinsic theoretical fragility of the EAT.

Robert Boyer (2012) analyses the specific conjunctures under which, in the past, austerity measures might have been expansionary in a few small open economies. In doing so, he stresses that there is "no general theoretical reason to guarantee the success of any austerity policy (Boyer, 2012, p.297)". Although detailed, Boyer's analysis remains purely argumentative. Boyer does not provide any formal treatment of his points; he does not frame his arguments into a model through which one can quantitatively define the restrictive conditions and perhaps implausible circumstances under which austerity-led expansion might hypothetically take place.

Thomas Palley (2010) shows the contractionary short-run effects of debt-capping fiscal rules. Yet, these effects are the direct in-built results of Palley's oversimplified closed-economy model, which is intrinsically at odds with EAT's theoretical apparatus. In our view, this fact makes Palley's critique rather sterile. In this paper we try to challenge the EAT "from the inside", by presenting a more general model that includes some core EAT-like assumptions, and showing the extreme and unrealistic conditions under which expansionary austerity might in principle be successful.

Foresti and Marani (2014) propose a simple short-run model in which fiscal austerity might have expansionary outcomes depending on the degree of coordination between monetary and fiscal policy, and on the extent to which monetary policy's adapted to fiscal retrenchments. In their work, Foresti and Marani (2014) define austerity as a given reduction in public deficit. By adopting this simplistic definition, they do not consider the specific policy content of fiscal retrenchments (i.e. cuts in expenditure versus tax increases) which, according to EAT supporters, could actually render austerity measures expansionary. On top of this, they unduly take the positive effect of fiscal corrections on public deficit for granted.

In this paper, we propose a simple model that tries to formalize Robert Boyer's (2012) general argumentative analysis. In doing this, we extend Palley's model by applying it to an open-economy model and by avoiding considering the results of austerity measures as in-built With respect to Foresti and Marani (2014), our model examines the policy measures composing austerity packages in more detail. We create an actual model of the cuts in public transfers and in public employees' salaries (plus future expected reductions in taxes) that EAT supporters advocate as potentially expansionary. Moreover, we also allow for a wider range of outcomes of austerity measures on public deficit. Austerity measures may reduce public deficit if they turn out to be effective and have an expansionary impact on economic activity. Such a result, however, is by no means automatic. 
Austerity measures might alternatively lead to counterintuitive results, i.e. a worsening public balance deficit, if they make economic recession even deeper.

In this paper, we mainly aim at developing a theoretical critique of the EAT proposition that well-designed austerity measures can be conducive to growth even in the very short run and even during recessions (see Alberto Alesina, 2010). For this reason, our model has a short-run horizon, and only focuses on short-run dynamics, i.e. the effects of restrictive fiscal adjustments on economic activity and on public deficit. Accordingly, we assume all stock variables, i.e. the home economy capital stock $K$, the public debt $D$, and the outstanding amount of the private sector's debt towards banks $C R$, as given.

In our model, we assume an open demand-driven economy. Perhaps surprisingly, the demanddriven nature of our economy is not at all at odds with the logic of EAT. Of course, the advocates of EAT notice that austerity measures can foster economic growth in the medium/long run through some supply-side mechanisms ${ }^{2}$; however much of their emphasis is on the demand-side channels through which well-designed fiscal adjustments could boost economic activity and stimulate private consumption, investment expenditures and export demand. For instance, in a recent contribution on the validity of EAT, Alesina, Favero, and Giavazzi (2015) clearly point out that a decisive aspect of successful austerity packages lies in their capacity to stimulate the private sector's investment and consumption demand by fostering its confidence in the solidity of the domestic macroeconomic environment. Even more interestingly, they stress how such a peculiar aspect of (successful) expenditure-based fiscal consolidations versus (unsuccessful) tax-based adjustments "cannot be explained by (accompanying) supply-side reforms" (Alesina, Favero, and Giavazzi 2015, p.37). In a way, EAT's attention for demand-side factors is a direct consequence of its non-Keynesian perspective on the effectiveness of fiscal policies, and of its belief in a negative fiscal multiplier. Due to the short-run nature of the model presented in this paper, we focus our attention on the operativeness only of the demand-side channels and consider it as the basis of EAT.

In this framework, equations (1) - (8) describe the supply side of the economy. We assume that production is carried out through a fixed-coefficient production function, in which $\alpha$ is the average labour productivity and $\sigma$ is the average productivity of capital. In equation (1), $L$ stands for the total available labour force, $K$ for installed capital, and $Y^{*}$ for potential output. In order to make our analysis as simple as possible, we assume that bottlenecks on the supply side of the economy could possibly emerge due to lack of labour, while there is always some amount of idle capital stock (Lavoie, 2015). Accordingly, potential output ( $\left.Y^{*}\right)$ effectively corresponds to the production level that would be achieved if the labour force $(L)$ were fully employed.

(1) $Y^{*}=\min (\alpha L, \sigma K)$

In our demand-driven economy, current output $(Y)$, the employment level $(N)$, and capacity utilization $\left(\chi=Y / Y^{*}\right)$, which is our measure of the output gap, are determined by effective demand. Accordingly, equation (2) defines the output/capital ratio as the product between capacity utilization $\chi$, and $\beta=Y^{*} / K=\sigma K^{f} / K$ (i.e. the highest degree of capital utilization that is achieved when production is at full potential, $K^{f}$ being the amount of "operative" capital out of the available capital stock).

(2) $\frac{Y}{K}=\frac{Y}{Y^{*}} \frac{Y^{*}}{K}=\chi \beta$ 
Equation (3) defines the employment level $(N)$ as a function of the demand-determined level of output (Y), while equation (4) sets the unemployment rate $(u=(L-N) / L=U / L)$ as a function of capacity utilization.

(3) $N=Y / \alpha$

(4) $u=\frac{L-N}{L}=1-\frac{Y}{\alpha L}=1-\chi$

Equations (5), (6) and (7) define the nominal wage rate $w$, the domestic price level $p_{H}$, and the real exchange rate $q$. In equation (6), domestic firms set the domestic price level $p_{H}$ by applying a mark-up $m$ on variable unit costs $w / \alpha$. In equation (5), nominal wages are established through a bargaining process between trade unions and firms. We assume the nominal wage $w$ to be positively related to the expected price level $p^{e}$ and to the degree of labour market protection $z$, which is in turn a positive function of unemployment benefits $b_{u}$. We also assume current nominal wage rates to be negatively influenced by the previous period's unemployment $u_{-1}$, since it would reduce trade unions' bargaining strength in the contemporary round of wage negotiations.

(5) $w=P^{e} l\left(\alpha, u_{-1}, z\left(b_{u}\right)\right)$

(6) $P_{H}=(1+m) \frac{w}{\alpha}$

(7) $q=\frac{e P^{F}}{P_{H}}=\frac{e P^{F} \alpha}{(1+m) P^{e} l\left(\alpha, u_{-1}, z\left(b_{u}\right)\right)}$

According to equation (8), the value of production is distributed between the total wage bill $W$ and aggregate profits $\Pi$.

(8) $P_{H} Y=W+\Pi=w N+\Pi$

Equations (9) - (14) describe the demand side of the economy. Equation (9) gives us the equilibrium condition for the goods market and breaks down all the components of the aggregate demand, i.e. domestic consumption $C$, domestic investments $I$, public purchases $G$, and net exports $N X$.

(9) $Y=C+I+G+N X$

Equation (10) describes aggregate consumption as a function of wage earners' and profit earners' saving propensities, $s_{w}$ and $s_{\pi}$ respectively. Total consumption depends on disposable income. In the case of wage earners, this is defined as the sum of the total wage bill $W(=w N)$, public transfers $\operatorname{Tr}^{G}$ and unemployment benefits $b_{u} U$ provided by the domestic social security system. The domestic government levies a tax rate $t_{w}$ on this kind of income. Profit earners' income is given by the difference between total profits $\Pi$ minus interest payments on the total amount of (past and present) loans received from banks, i.e. $i_{c r} C R$. The tax rate levied on net profits is $t_{\pi}$. In this model, the domestic bank system gets interests on the outstanding amount of private loans $(C R)$ and public debt $D$. We assume that it does not pay any interest rate on deposits possibly held by 
households. For the sake of simplicity, we also assume that banks save all their realized profits (i.e. the difference between positive and negative interests), so that banks' profits do not play any role in determining aggregate consumption. For the sake of simplicity, equation (10b) scales down aggregate consumption for the capital stock $K$. Accordingly, $\rho$ and $\lambda$ stand for normalized values of public transfers and private debt, respectively; $r$ is the profit share

(10) $C=\left(1-s_{w}\right)\left(1-t_{w}\right)\left[w N+\operatorname{Tr}^{G}+b_{u} U\right]+\left(1-s_{\pi}\right)\left(1-t_{\pi}\right)\left[\Pi-i_{c r} C R\right]$ or:

(10b) $\frac{C}{K}=\overline{c_{o}}+c_{w}\left[\frac{\beta}{\alpha}\left(w-b_{u}\right) \chi\right]+c_{r} r \beta \chi$

With $\overline{c_{o}}=\left(1-s_{w}\right)\left(1-t_{w}\right)\left[b_{u} \frac{\beta}{\alpha}+\rho\right]-\left(1-s_{\pi}\right)\left(1-t_{\pi}\right) i_{c r} \lambda ; c_{w}=\left(1-s_{w}\right)\left(1-t_{w}\right)$ and $c_{r}=\left(1-s_{\pi}\right)\left(1-t_{\pi}\right)$.

Equation (11) defines the concurrent growth rate of the capital stock. Taking inspiration from Bhaduri and Marglin (1990), we assume $(I / K)$ to be a positive linear function of capacity utilization $\chi$ and of the profit share $r$ (with $a$ and $v$ as the corresponding parameters). Domestic investments are also negatively affected by the interest rate $i_{c r}$ on banks' loans via the parameter $h$. Keynesian-type animal spirits are captured by parameter $\eta$.

(11) $\frac{I}{K}=\eta+a \chi+v r-h i_{c r}$

Equation (12) gives us public purchases, once again normalized for the capital stock $K$, as an exogenous policy variable $\gamma$.

(12) $\frac{G}{K}=\gamma$

In equation (13), normalized net exports are a linear positive function of the real exchange rate $q$, while they depend negatively on domestic capacity utilization $\chi$.

(13) $\frac{N X}{K}=\epsilon_{q} q-\epsilon_{\chi} \chi$

Finally, equation (14) introduces a crucial assumption that hinges directly on the EAT logic. Equation (14) assumes that, in an intertemporal time framework and in line with a permanent income argument, current households' saving propensity may be positively dependent on the expected future tax rate $t_{w}{ }^{e}$. Current cuts in public expenditures, if sufficiently strong and reliable, may induce households to increase current consumption since that they may expect a lower tax burden tomorrow. At the same time, we also assume that households' saving propensity is negatively dependent on public transfers. Indeed, it is reasonable to believe that a permanent cut in public transfers, perhaps due to the policy decision of downsizing the provisions of the domestic welfare system, may also induce households to save more today in anticipation of lower public transfers tomorrow ${ }^{3}$.

(14) $s_{w}=f\left(t_{w}^{e}, \operatorname{Tr}^{G}\right)$ with $\left(\partial s_{w} / \partial t_{w}^{e}\right)=f_{t_{w}^{e}}>0 ;\left(\partial s_{w} / \partial T r^{G}\right)=f_{T^{G}}<0$ 
Last but not least, equations (15) - (17) formalize the public budget and the financial block of our economy, i.e. how the interest rates are determined and how they change.

Equation (15) defines public balance deficit as the difference between government outlays, i.e. government purchases, public transfers, the total amount of unemployment benefits and interest payments on public debt $i_{d} D$, and government revenues from taxes on households and firms. For the purpose of our analysis, equation (15b) redefines the public balance deficit as a ratio of GDP:

(15b) $b=\frac{B}{K} \frac{K}{Y^{*}} \frac{Y^{*}}{Y}=\frac{\xi(\chi)}{\beta \chi}$

With $\xi=\left\{\gamma+\left(1-t_{w}\right)\left[b_{u} \frac{\beta}{\alpha}(1-\chi)+\rho\right]+\left(1-t_{\pi}\right) i_{d} \Delta-t_{w} w \frac{\beta}{\alpha}-t_{\pi} r\right\}$ as the public deficit-to-capital stock ratio and $\Delta=D / K$ as the public debt-to-capital stock ratio. From equation (15b), it is easy to verify that the deficit-to-GDP ratio depends negatively on capacity utilization $\chi$, due to the negative effect $\chi$ carries out on public deficit, as well as the positive one it carries out on economic activity, i.e. the denominator of the deficit-to-GDP ratio itself.

In equation (16) we assume that banks establish an interest rate $i_{c r}$ on private loans by applying a mark-up rate $\mu$ on the interest on public bonds $i_{d}$. Indeed, in our model financial operators, say commercial banks, hold two types of assets on their balance sheet. On the one hand, they buy domestic government bonds. On the other, they give loans to firms. Government bonds are generally considered "relatively" safer assets with respect to private loans. Following Mehrling (2011), government bonds constitute the collaterals used by financial operators in refinancing operations with the central bank. Also, they can be "shifted" onto the balance sheet of some other institution quite easily. This is not the case for loans made to the private sector. Once created, loans to the private sector are more likely to remain on the balance sheet of the originating institutions until maturity (unless shadow banking financial engineering transforms and securitizes them into allegedly riskless assets!), along with the corresponding risk taken on by the creditor. Accordingly, financial institutions may ask for extra remuneration on loans to the private sector with respect to yields on government bonds.

(16) $i_{c r}=(1+\mu) i_{d}$

In equation (17), we set out the determinants of the interest rate $i_{d}$ on public debt:

(17) $i_{d}=\phi(b, \Omega)$ with $(\partial \phi / \partial b)>0$ if $\Omega=0 ;(\partial \phi / \partial b)=0$ if $\Omega=1$

We first assume that $i_{d}$ is a positive function of the current public budget deficit over GDP (b), rather than of the debt-to-GDP ratio. We make this assumption because of the short-run nature of our model, in which the stock of debt is taken as a given. We also do it in order to analyse in more detail how final retrenchments and the ensuing change in some "sensible" fiscal variables - such as the fiscal deficit - as well as the interest rates on bonds (i.e. their measure of riskiness) might interact when implementing austerity programs ${ }^{4}$. According to the logic of the EAT, in equation (17) we assume that policy-makers could reduce financial operators' yield claims on government bonds by shrinking public deficit, or better by reducing it by such a large amount that they prompt a reduction in the debt-to-GDP ratio. 
Secondly, we assume that the abovementioned link between $i_{d}$ and $b$ is fundamentally influenced by the degree of monetary sovereignty of the economy that is being considered. In our model, we capture this point through the "institutional" variable $\Omega$. We conceive $\Omega$ as a bivariate variable, taking value 1 in the case of a monetarily sovereign country like the US, or 0 in the case of countries that are not monetarily sovereign, such as Eurozone Member States, which issue bonds denominated in a supranational "foreign" currency. In a monetarily sovereign country, public bonds are usually taken as risk-free assets, since they are denominated in the currency issued by the domestic central bank, so the domestic central bank can intervene any time it likes to prevent the emergence of default risks. Accordingly, we assume $i_{d}$ to be insensitive to the evolution of the public deficit (surplus) over GDP. This assumption is underpinned by some recent empirical evidence that in the context of "stand-alone" (monetarily sovereign) countries, government bond yields do not respond to economic fundamentals such as the solidity of public finances, the growth rate of the economy and surpluses in the current account of the Balance of Payments (see De Grauwe and Ji, 2013) $)^{5}$. The institutional setting of the Eurozone is different. Eurozone rules impose national governments to find resources only on private financial markets, and forbid the ECB from buying public bonds (at least on the primary market), thus from directly financing national governments. As a consequence, the solidity of Eurozone national finances is in the hands of financial operators. They would likely "downgrade" Eurozone sovereign bonds by the same standard as other private corporate bonds issued on financial markets, with the corresponding degree of riskiness depending on the (perceived) soundness of public finances. The positive link between $i_{d}$ and public deficit $(b)$ will likely emerge.

In our simple model, we can find an explicit expression for the level of capacity utilization $\chi$ that ensures equilibrium in the goods market. Analytically, by plugging equations (10.b) - (13) into (9), and by taking into account equations (16) - (17), we get:

(18) $\chi=\frac{\overline{c_{o}}+\eta+v r+\gamma+\epsilon_{q} q-h(1+\mu) \phi(b)}{\Lambda}$

With $\frac{1}{\Lambda}=\frac{1}{\left[\beta-c_{w} \frac{\beta}{\alpha}\left(w-b_{u}\right)-c_{r} \beta-a+\epsilon_{\chi}\right]}$ as the Keynesian multiplier. The Keynesian multiplier is a negative function of $s_{w}, s_{\pi}$, and of the "import coefficient" $\epsilon_{\chi}$. Moreover, it decreases when unemployment benefits $b_{u}$ increase if $\left(\partial w / \partial b_{u}\right)<1$ and, hence, $\left(\partial \Lambda / \partial b_{u}\right)=-c_{w}(\beta / \alpha)\left[\left(\partial w / \partial b_{u}\right)-1\right]>$ 0 . Such an effect is due to the fact that higher unemployment benefits reduce the multiplicative effects that any increase in the autonomous components of aggregate demand, by stimulating economic activity, employment and hence consumption, tend to induce on economic activity itself. In a very Keynesian fashion, equation (18) states that current capacity utilization is a positive function of all demand injections, while it depends negatively on those factors that reduce investments, consumptions and net exports. Despite the negative effect $b_{u}$ bears on the Keynesian multiplier $(1 / \Lambda)$, it is easy to show that more generous unemployment benefits prompt an economic expansion (i.e. $\chi$ increases) by raising $\overline{c_{o}}$.

Finally, note that equation (18), together with equation (15b), forms a system of two equations in two unknown variables $(\chi$ and $b$ ). Such a system is at the centre of the "fiscal policy experiments" through which we analytically investigate the short-run effects of well-designed (and supposedly expansionary) fiscal consolidations. 


\section{The short-run macroeconomic effects of cuts in public transfers}

Let assume that the government implements a restrictive fiscal adjustment, causing the cyclically adjusted primary public balance (CAPB) to decrease by an amount equal to $-\theta$. Moreover, assume that fiscal consolidation mainly takes the form of a cut in public transfers (i.e. $d T r^{G}<0$ ). In terms of our model, if we define the CAPB as $b^{*}=\frac{1}{\beta}\left[\gamma+\left(1-t_{w}\right) \rho-t_{w} w-t_{\pi}\left(r+i_{d} \Delta\right)\right]$, we get:

(19) $d b^{*}=-\theta=\frac{\left(1-t_{w}\right)}{\beta} d \rho=\frac{\left(1-t_{w}\right)}{\beta K} d \operatorname{Tr}^{G}$, so that: $d \operatorname{Tr}^{G}=-\frac{\beta K}{\left(1-t_{w}\right)} \theta$

With $\theta>0$.

In our model, such a fiscal adjustment has a direct and simultaneous short-run effect on both current capacity utilization $\chi$ and the deficit-to-GDP ratio $b$. Differentiating $\chi$ and $b$, and taking into account the sign of equation (19), we get a system of 2 simultaneous equations for $d \chi$ and $d b$ :

$$
\left\{\begin{array}{c}
d \chi=\frac{1}{\Lambda}\left\{\left[\left(\frac{\partial \overline{c_{o}}}{\partial s_{w}}\right)-\left(\frac{\partial \Lambda}{\partial s_{w}}\right) \chi\right] f_{t_{w}^{e}} d t_{w}^{e}-\left[\left(\frac{\partial \overline{c_{o}}}{\partial s_{w}}\right)-\left(\frac{\partial \Lambda}{\partial s_{w}}\right) \chi\right] \frac{\beta K}{\left(1-t_{w}\right)} f_{T^{G}} \theta+\left[\left(\frac{\partial \overline{c_{o}}}{\partial i_{c r}}\right)-h\right](1+\mu) \phi_{b} d b\right\} \\
d b=-\frac{K}{\chi} \theta-\Gamma d \chi
\end{array}\right.
$$

With $\frac{\partial \overline{c_{o}}}{\partial s_{w}}<0 ; \frac{\partial \Lambda}{\partial s_{w}}>0 ; \frac{\partial \overline{c_{o}}}{\partial i_{c r}}<0 ;\left(\phi_{b} \mid \Omega\right) \geq 0 ; d t_{w}^{e}<0 ; \Gamma=\left[\frac{\left(1-t_{w}\right)\left(b_{u} / \alpha\right)}{\chi}+\frac{b}{\chi}\right]>0$

Equations (20) and (21) below give the solutions $d \chi^{S}$ and $d b^{S}$ of the system (S.1) reported above:

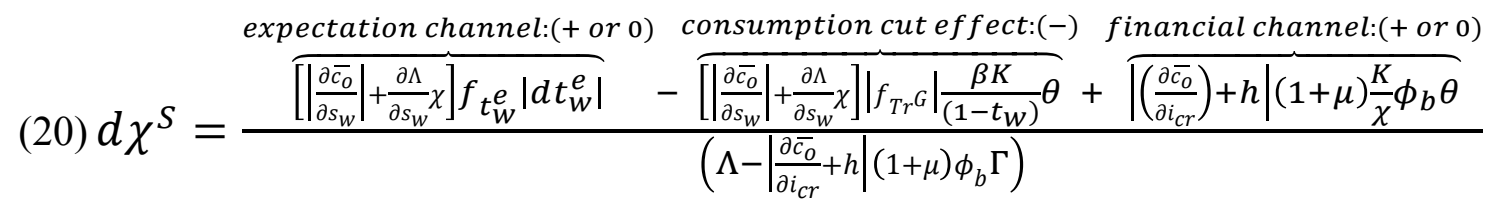

(21) $d b^{S}=-\frac{K \theta}{\chi}-\Gamma d \chi^{S}$

What emerges is that there is not a clear-cut outcome of the restrictive fiscal policy as we had assumed, due to the several conflicting forces that can work simultaneously. The sign of equation (20) may turn out to be either positive, confirming the expansionary austerity hypothesis, or negative, in line with the traditional Keynesian concern about the recessionary effects of fiscal retrenchments. The same applies to equation (21). Cuts in public transfers might help reduce public deficit over GDP but, on the other hand, they could be counterproductive and lead to an even higher deficit-to-GDP ratio if they trigger a strong contraction of economic activity. Despite such indeterminacy, a few points are worth stressing:

1. The expansionary outcome of fiscal adjustment heavily depends on the intensity of partial derivatives $f_{t_{w}^{e}}$, and $\left|d t_{w}^{e}\right|$, i.e. the expected reduction (here reported in absolute value) in the tax burden levied on households. The higher and the quicker $\left|d t_{w}^{e}\right|$ is, the more rapidly and robustly private consumptions might respond to public budget's cuts positively. Interestingly, and perhaps paradoxically, such positive expectations will hardly materialize in an economy 
characterized by a high public debt stock, i.e. the economic scenario in which, according to EAT supporters, fiscal consolidation is primarily needed. Indeed, when public debt $D$ is considerably high and a prolonged period of fiscal consolidation is foreseen, people will likely expect future tax reductions to be modest and take place much farther ahead (at least with respect to current spending cuts). In other words, a high degree of uncertainty would "surround" the extent and the timing of future tax cuts. In such a context, the "expectation channel" through which expansionary austerity may work is extremely weak at best, and likely more than compensated by the overwhelming contractionary effect of the simultaneous cuts in public transfers.

2. Cuts in public transfers, EAT proponents argue, may also boost growth by reducing public deficit, hence reduce interest rate $i_{d}$ on public bonds and, indirectly, interest rate $i_{c r}$ on banks' loans to the private sector. Such a reduction in the cost of external financing may in turn spur private investments and induce the economy's expansion. According to our model, fiscal adjustments on interest rates can hardly have this effect on monetarily sovereign economies. Indeed, following equations (16) and (17), in monetarily sovereign countries the "financial market channel" through which fiscal consolidation may affect economic dynamics is likely to disappear (i.e. $\phi_{b}=0$ ). Accordingly, in equation (20), the allegedly expansionary impact of fiscal consolidation turns out to be weak at the very best.

The "financial channel" might function when Eurozone countries issue public bonds denominated in a supranational currency; in this case, the solidity of public finances and of the overall financial system is dependent on financial markets' sentiments. In such a context, one could be persuaded that front-loaded fiscal adjustments might reassure financial markets about the sustainability of Eurozone countries' fiscal positions, and is more probable to eventually entail expansionary effects. This logic might hold true if fiscal adjustments effectively lower public deficit and the debt-to-GDP ratio. Yet, we are very far from taking such an effect of fiscal consolidation for granted. Recent empirical evidence shows that it is hard to find a way out from public balance disarrays without sustained growth (Ali Abbas et al., 2013), and that fiscal multipliers are high and positive when economies are in the midst of a recession or are operating below potential (Auerbach and Gorodnichenko, 2012; Qazizada and Stockhammer, 2015). If so, excessively severe and premature fiscal retrenchments may actually induce a short-run deterioration (rather than an improvement) of fiscal and financial variables, by jeopardizing growth performances ${ }^{6}$.

Figure 1 graphically portrays such a perverse outcome of restrictive fiscal measures. In the upper panel of Figure 1, we report the left-hand-side (LHS) of equation 1 in system (S.1), i.e. a 45degree sloping curve, along with the right-hand-side (RHS) of equation 1. Note that the RHS curve depends on $d \chi$ because economic expansion has a positive feedback on its own dynamics through its impact on the deficit-to-GDP ratio. Changes in the position of the RHS curve depend on the "autonomous" direct effects discretionary budget cuts (i.e. $\theta$ ) have on economic activity via the "expectation" channel and the "financial" channel. Upward shifts of the RHS curve stand for austerity measures that are expansionary from the onset. Downward movements of the RHS curve are due to an austerity-led initial contraction in economic activity. In the bottom panel of Figure 1 we show how the deficit-to-GDP ratio decreases $(d b<0)$ when the economy expands $(d \chi>0)$, see equation 2 in system (S.1). A relatively flat (steep) " $d b$ " curve stands for a deficitto-GDP ratio that is relatively insensitive (highly responsive) to changing economic activity. The position of the " $d b$ " curve in Figure 1 depends on the negative direct effect austerity measures induce on public deficit. 
Let us assume that at the beginning of an austerity program, the "expectation" channel is weak, and/or interest rates do not respond to the announcement of public budget cuts intensively enough. In such a context, fiscal austerity is likely to reduce economic activity and make $d \chi$ negative (see downward movement of the RHS curve in the upper part of Figure 1). Fiscal austerity may initially reduce fiscal deficit (see the initial leftward movement of the " $d b$ " curve, and the move from equilibrium point $A$ to point $B$, in the bottom part of Figure 1). Yet, it may later turn out to be self-defeating and frustrate governments' efforts to stabilize fiscal variables because of the abovementioned recessionary effects (see movement from point $B$ to equilibrium $C$ in Figure 1). Austerity-led recession risks eventually increasing fiscal disarrays rather then reducing them, thereby creating further tensions on financial markets.

\section{[Figure 1 here]}

Things could get dramatically worse with the presence of a strong "financial" channel, in cases such as when: financial operators overreact to changes in public deficits $\left(\phi_{b}>>0\right)$; improvements in public balance are over-dependent on changes in economic activity $(\Gamma>>0)$; austerity measures are even slightly contractionary from the onset. In these contexts, the RHS of equation 1 in system (S.1) becomes steeper than the LHS (see Figure 2). Correspondingly, the denominator in equation (20) turns out to be negative, short-run Keynesian instability emerges, and short-run equilibrium is disrupted. Although discretionary budget cuts could per se reduce public deficit, even a subsequent small economic contraction can eventually increase fiscal disarrays. Financial panic erupts when public finance conditions worsen, and interest rates skyrocket. Economic recession deepens and gives rise to an endless "race to the bottom", which will inevitably end up in a public debt default and a tremendously painful economic dislocation (see endless right-to-left movement in Figure 2). This kind of dynamics sadly resembles the one observed in Greece starting from 2010. Eventually, the results of fiscal cuts could be opposite to those expected by EAT supporters even when the "financial" channel does significantly affect macroeconomic real and financial variables.

\section{[Figure 2 here]}

3. Last but not least, after 2012, the monetary scenario now prevailing in the Eurozone closely resembles the one that has characterized the US since the outbreak of the worldwide financial crisis. Indeed, thanks to Mario Draghi's "whatever it takes" pledge to save the euro, financial speculation on peripheral countries' government bonds has calmed down, and interest rates $i_{d}$ have decreased significantly. In such a context, it makes sense to question the effectiveness of the "financial" channel through which fiscal austerity is expected to positively contribute to economic recovery. As Roberto Perotti himself stresses, "if fiscal consolidations were expansionary in the past because they caused a steep decline in interest rates or inflation, it is unlikely that the same mechanism can be relied on in the present circumstances, with low inflation and interest rates close to zero (Perotti, 2013, p.309)".

\section{The short-run macroeconomic effects of lower unemployment benefits}

An additional proposition of the EAT is that well-designed austerity packages should also encompass cuts in public wages, reduction in public employment and cuts in unemployment benefits $b_{u}$. The aim would be to establish a climate of wage rate moderation (i.e. a lower nominal 
wage rate $w$ ) and to improve the external competitiveness of the economy. In our model, system (S.2) formalizes the short-run effects of a reduction in unemployment benefits $b_{u}$ :

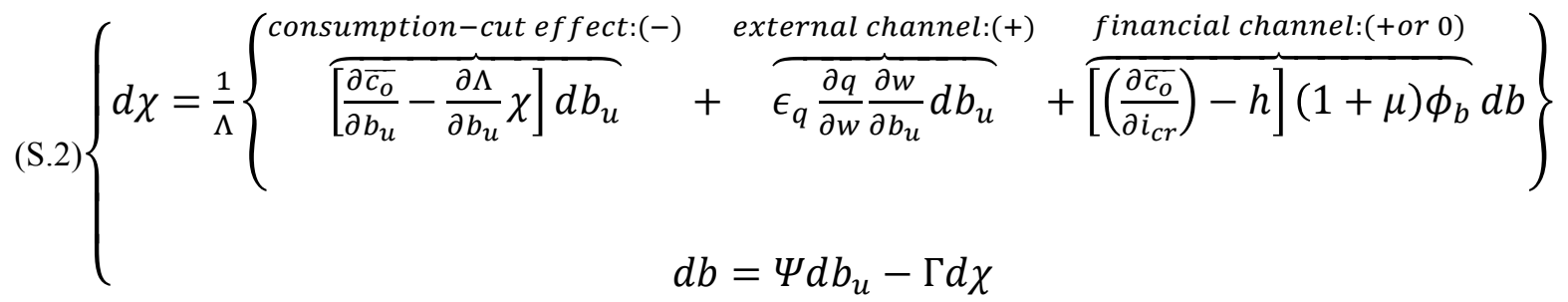

With $\Psi=\frac{1}{\alpha \chi}\left[\left(1-t_{w}\right)(1-\chi)-t_{w}\left(\frac{\partial w}{\partial b_{u}}\right)\right]>0$ if $\left(1-t_{w}\right)(1-\chi)>t_{w}\left(\frac{\partial w}{\partial b_{u}}\right) ;\left(\partial w / \partial b_{u}\right)>0 ;(\partial q / \partial w)<0$; $d b_{u}<0$. Equations (22) and (23) give the solutions of system (S.2):

(22) $d \chi^{S 2}=\frac{\overbrace{\left\{\left[\frac{\partial \overline{c_{0}}}{\partial b_{u}}-\frac{\partial \Lambda}{\partial b_{u}} \chi+\epsilon_{q} \frac{\partial q \partial w}{\partial w \partial b_{u}}\right]-\left|\frac{\partial \overline{c_{0}}}{\partial i_{c r}}+h\right|(1+\mu) \phi_{b} \Psi\right\}}^{?} d b_{u}}{\left\{\Lambda-\left|\frac{\partial \overline{c_{0}}}{\partial i_{c r}}+h\right|(1+\mu) \phi_{b} \Gamma\right\}}$

(23) $d b^{S 2}=\Psi d b_{u}-\Gamma d \chi^{S 2}$

Once again, there are no clear-cut solutions, and the theoretical basis of the EAT seems extremely weak. In particular, the direct effect of a cut in unemployment benefits is a lower demand injection in the form of lower consumption expenditures. This would certainly deepen recession instead of prompting recovery. The contraction in the domestic component of aggregate demand might be compensated by an increasing external demand for homemade goods that might emerge in presence of lower domestic nominal wages $w$ and, thus, of a depreciated real exchange rate $q$. However, increasing net exports, possibly resulting in booming economic activity, strongly relies on the sensitivity of net exports to the real exchange rate (i.e. parameter $\epsilon_{q}$ in equation (22)), which in turn depends on the sectorial composition of net exports themselves and on the economy's degree of openness (see Taylor, 1991). It is perhaps not by chance that one of the most cited examples of successful expansionary austerity is the one that took place in Ireland in the late 1980s. Ireland is a small open economy that is highly integrated in the international goods markets, and that exports a limited but highly dynamic variety of manufactured products (pharmaceutical products, for instance). At the end of the 1980s Irish exports were already accounting for more than 50 percent of Ireland's GDP. Perotti (2013) himself recognizes that a fundamental pillar of the late 1980s Irish economic rebound was the solid expansion of Irish exports due to domestic wage moderation and quick reduction in inflation along with the initial one-shot devaluation of the Irish pound and the economic expansion of Ireland's most important trade partner, Britain. Today, part of the above policy recipe, i.e. the devaluation of the domestic currency, is no longer available in Eurozone countries. Moreover, it is questionable that a small peripheral Eurozone country like Greece could currently follow that same development pattern. Indeed, Greece has a small, relatively closed and largely de-industrialized economy. Accordingly, there are reasonable doubts that the emphasis on internal devaluation, as sponsored by the EAT supporters, could currently give rise to the same results in Greece as wage moderation supposedly did in Ireland when combined with other currently unavailable policy options and when applied in a much more favourable worldwide economic scenario. 


\section{From theory to empirical evidence.}

The model presented in the previous section allows for a wide range of outcomes as a consequence of the many conflicting forces that are at work at the same time. In this sense, it is worth noting that the inclusion in our model of some EAT-like mechanisms and the formalization of allegedly welldesigned fiscal retrenchments still do not ensure the success of fiscal austerity. This success depends on numerous parameters, such as the elasticity to changes in public finance variables of government bonds' interest rates, the sensitivity of the lending rate on private sector loans to government bond yields, as well as the exports' price elasticity and the pass-through rule connecting labour unit cost to the real exchange. Another important variable is the change in economic agents' expectations, which is, to say the least, quite hard to measure and predict.

To some extent, empirical analysis could reduce such theoretical indeterminacy. Figures 3, 4, and 5 provide some prima facie evidence of the effectiveness of austerity policies since 2010 (i.e. since the first year in which most developed countries returned to, or adopted, consolidation plans after the short-lived implementation of counter-cyclical measures taming the real-side effects of the 2007-2008 financial meltdown). In line with standard practice in the EAT literature, Figures 3, 4 and 5 show the direct relationship between discretionary adjustments, as measured by changes in the CAPB, and the overall GDP growth rate (Figure 3), the growth rate of private consumption (Figure 4), and the dynamics of fixed private capital formation (Figure 5). We refer this analysis to a sample of 28 developed countries (see Table A.1 in the Appendix), which includes both monetarily sovereign and non-monetarily sovereign (or Eurozone) countries.

[Figure 3 here]

[Figure 4 here]

[Figure 5 here]

Figures 3, 4, and 5 all suggest that post-crisis austerity did not deliver any of the expected expansionary outcomes. Indeed, a negative correlation seems to run between consolidations in the CAPB and overall GDP growth, and the dynamics of the domestic private components of GDP.

This empirical analysis is overly simple and can only provide a superficial impression of the consequences of fiscal austerity in the post-financial crisis period. In this section we thus go into more detail on the functioning of the EAT. More specifically, we point out that the empirical literature supporting the EA hypothesis usually only focuses on the final outcome of austerity measures, i.e. their final effects on overall output growth, consumption, and investment growth (see Alesina and Perotti, 2007; Alesina and Ardagna, 2010 and 2012). However, this literature largely neglects testing the empirical validity of the several mechanisms through which well-designed fiscal consolidations are expected to promote economic expansion. In this paper, we expand on that observation and fill the gap in the literature by developing a detailed empirical investigation on the functioning of the "financial", "external", and "expectation" channels in the post financial crisis period.

As to the "financial" channel, we follow a two-step approach. In the first step, we test the relevance of fiscal policy variables (i.e. variations in the CAPB) and public balance magnitudes such as the debt-to-GDP ratio, on the determination of government bond yields $\left(i_{d}\right)$. This way, we verify whether restrictive fiscal policies that overtly aim at abating public deficit and reducing the 
debt burden can possibly lower $i_{d}$. In the second step, in accordance with our theoretical setting, we check for the effects that austerity measures might have on (external) financing costs of private investment via the connection between $i_{d}$ and banks' lending rate on private loans $\left(i_{c r}\right)$. The hypothesis we will put to a test is that fiscal consolidations, by making public finances safer, can prompt a general reduction in interest rates, thereby stimulating private investment (see equations (24), (25), and (29) below). Consistently with our theoretical framework, we also investigate how the differences in the institutions in charge of monetary policies, namely the degree of sovereignty with which public bonds are issued, may shape and alter the abovementioned mechanisms at the heart of the "financial" channel.

As to the "external" channel, the question we focus our attention on is whether fiscal consolidations can eventually boost exports by depreciating the real exchange rate via wage moderation and internal devaluation. We adopt a two-step approach in this case as well. We first look at the causality relationship between fiscal policies and the real exchange rate (see equation (26) below). We then estimate the price elasticity of exports to changes in the real exchange rate (equation (27)).

We finally investigate on the operativeness of the "expectation" channel by looking at the relationship between yearly variations in the CAPB, i.e. "our" measure of discretionary fiscal policy and private consumption and investment growth rates. With respect to the simple correlation analysis portrayed in Figures 4 and 5, equations (28) and (29) now take into account many more variables as possible additional explicative factors of domestic consumption and investment. For instance, in equations (28) and (29) we test for the wage- or profit-led nature of consumption and investment expenditures, given the distributive effects that fiscal retrenchments are likely to entail. Also, equation (29) tests for the link between gross fixed capital formation and the costs of external financing $\left(i_{c r}\right)$, a fundamental element of the abovementioned "financial" channel. The following section 3.1 illustrates the details and the results of our empirical investigation on the foundations of the EAT.

\section{An empirical assessment of the foundations of the EAT.}

Our empirical investigation relies on the annual data taken from a sample of 28 developed economies from 2007 to 2016, which corresponds to an unbalanced panel dataset of 216 annual observations $^{7}$. As already mentioned, we include both monetarily sovereign and non-monetarily sovereign (i.e. Eurozone) countries in our sample. As to the methodology of the estimation, after having ruled out the estimation of a random effect model through a Hausman test, we opted for a fixed effect model. The fixed effect model checks for unobserved time-invariant effects, and produces unbiased estimates under the assumption of the strict exogeneity of independent variables (i.e. explanatory variables uncorrelated with idiosyncratic errors $\varepsilon_{i t}$ in each time period). This could be quite a strong assumption. In fact, fiscal and monetary policy variables might be interpreted as weakly endogenous responses to the evolution of the economic cycle. This fact notwithstanding, we adopted a fixed effect model for three main reasons. First, the spread of the "austerity mantra" after 2009 has turned fiscal consolidation into something of a strictly discretionary, therefore exogenous policy stance to pursue regardless of the state of that specific economy. Second, the extreme actions taken by ECB in 2012 can be interpreted as consequences of, and responses to mounting financial turbulences in the Eurozone. Nonetheless, Mario Draghi's "whatever it takes" statement and the launch of the Outright Monetary Transaction (OTM) programme also represent hotly disputed, discretionary and, in some extent, exogenous institutional breaks through which "the ECB set itself as the lender of last resort standing behind Eurozone sovereigns in case of large idiosyncratic 
financial shocks (Micossi, 2015, p.15)". They introduced a structural discontinuity in the behaviour of monetary institutions in the Eurozone, at least potentially (the OMT programme has been effectively never utilized!). In a way, they certainly structurally altered financial operators' perception as to the role of the ECB in backstopping possible financial crises. Finally, the nature of our analysis, as well as the limited data availability, does not allow us to adopt more sophisticated modelling strategies that check for the various degrees of endogeneity (e.g. IV estimators, GMM, etc.). Last but not least, our fixed effect model follows precisely the same approach used by most previous empirical investigations about the relationship between austerity policies and macrofinancial variables (see, for example, Giavazzi et al., 2005, as well as De Grauwe and Ji, 2013).

The structure of the relationship between the error term and the explanatory variables in a fixed effect model does not allow for the inclusion of time-constant variables. However, these variables are important in our analysis, since we want to analyse the role of institutional differences (i.e. monetarily sovereign countries vs. non-monetarily sovereign ones) in shaping the effectiveness of macroeconomic policies. The most consistent way to overcome this issue is to combine time constant variables with relevant time-variant ones. This modality is superior to the previous estimations carried out on different samples that had been split according to the institutional factor at stake. When employing a fixed effect model, the choice of the goodness-of-fit measure is not straightforward. We follow the standard approach, and we choose the within- $R^{2}$ measure, i.e. the amount of time variation in the dependent variable explained by the time variation in the explanatory variables.

We test the validity of our specifications using two standard tests. First, we test for the existence of unit-roots using both the Fisher and Levin-Lin-Chu approaches (see Table A.2). Second, we assess the biasing presence of cross-sectional dependence with the Pesaran test, which also informed the inclusion/exclusion of time dummies in the various estimations (see Table A.3). All these tests support both our choices of specifications and the soundness of the estimations.

We investigate the econometric solidity of the foundations of the EAT through a set of six equations. Equations (24) and (25) test the main mechanisms at the basis of the "financial" channel.

(24) $i_{d}=a_{1} \Delta C A P B+a_{2} \Delta C A P B_{M S}+a_{3}\left(\frac{D}{Y}\right)+a_{4}\left(\frac{D}{Y}\right)_{M S}+a_{5} C C A+a_{6} C C A_{M S}+a_{7}\left(\frac{D}{Y}\right)_{M D R A G H I}+$ $a_{8} g_{i}+\varepsilon_{i t, 1}$

(25) $i_{c r}=b_{1} i_{d}+b_{2} \Delta C A P B+b_{3} \Delta C A P B_{M S}+b_{4} g+b_{5} i_{C B}+\varepsilon_{i t, 2}$

In equation (24), we explain how interest rates on 10-year government bonds $\left(i_{d}\right)$ are determined. We take yearly changes in the $C A P B(\triangle C A P B)$, i.e. the standard measure of discretionary fiscal policy in the EAT literature, as the first relevant explicative variable. According to equation (17), we also check for the relevance of public finance variables. In order to avoid multicollinearity issues with respect to changes in the $C A P B$, we use the debt-to-GDP ratio $(D / Y)$ rather than the deficit-to-GDP ratio. Indeed, this is consistent with financial operators' common practices, as they take the debt-to-GDP ratio as a leading indicator of public finance solidity. Beyond these variables, we consider the cumulative current account balance $(C C A)$ from 2007 on as third factor influencing interest rate determination. Following De Grauwe and Ji (2013), the $C C A$ is a proxy for the international financial position characterizing an economy over the relevant time spell. A positive (and increasing) $C C A$ is associated with countries that are creditors on international financial markets, i.e. Germany, Japan, and the other core Eurozone countries. Debtor monetary sovereign 
countries such as the USA and the UK, which have been able to continuously attract foreign capital even after the 2007-2008 financial shock, are characterized by an increasingly negative $C C A$. A negative but decreasing (or stabilizing) net international investment position is associated to peripheral Eurozone economies. In our regression, the $C C A$ is meant to capture the important role that net creditor (or debtor) positions on international financial markets might have played in determining the diverging dynamics of sovereign bond yields between central and peripheral Eurozone countries since 2008. According to the specification of equation (17) in our theoretical model, all the above variables are made to interact with a dummy variable $d_{M S}$ (see variables with subscript $M S$ ) in order to capture how monetary sovereignty may influence the functioning of the "financial" channel. This dummy variable takes value $l$ if country " $i$ " is monetarily sovereign, whilst takes value 0 if it is non-monetarily sovereign.

In the same vein, we introduce a "Mario Draghi" dummy (specific to the Eurozone countries) in equation (24), i.e. $(D / Y)_{M D R A G H I}$, in order to further assess the effects of the ECB president's "whatever in takes" statement on the determination of government bond yields in the Eurozone after 2012.

Finally, the growth rate of the economy $\left(g_{i}\right)$ is a control variable for the effects that a growing and expanding economy may have on government bonds' interest rates.

In line with equation (16), equation (25) tests the relationship between the lending rate on loans to the private sector $\left(i_{c r}\right)$ and the interest rate on government bonds $\left(i_{d}\right)$. We also check for any possible direct effect austerity measures may have on the costs of external financing. We run this analysis taking into account the specific monetary environment in which austerity measures are implemented (so whether the country is monetarily sovereign or not). In equation (25), we detect the effects of the growth rate of the economy $\left(g_{i}\right)$ on the lending rate, as well as the effects of the monetary policy stance adopted by the central banks as captured by the central bank policy rate $\left(i_{C B}\right)$.

Equations (26) and (27) focus on the "external" channel:

(26) $\left(\frac{1}{q}\right)=c_{1} \Delta C A P B+c_{2} C C A+c_{3} C C A_{M S}+c_{4} i_{C B}+\varepsilon_{i t, 3}$

(27) $g_{E X}=h_{1} g_{q}+h_{2} g_{R W}+\varepsilon_{i t, 4}$

Equation (26) analyses the determinants of the inverse real exchange rate $(q)^{8}$. We investigate whether austerity measures effectively triggered a devaluation of the real exchange rate (i.e. a reduction of $1 / q$ ), thereby improving the external competitiveness of the economy. We also estimate the extent to which the real exchange rate is related to the net international investment position characterizing monetarily sovereign and non-monetarily sovereign countries (see $C C A$ and $C C A_{M S}$ in equation (26)), and to the central bank's monetary policy stance $\left(i_{C B}\right)$.

Equation (27) aims to assess the relevance of changes in the real effective exchange rate $\left(g_{q}\right)$ and in the growth rate of the rest of the world $g_{R W}$ (with respect to any single economy included in our sample) for export dynamics $\left(g_{E X}\right)$. We take the percentage variation of exports as the dependent variable in order to avoid any autocorrelation problem.

Equations (28) and (29) test the "expectation" channel, and display the effects austerity might have on private consumption and gross fixed capital formation. Equation (28) follows the logic of the regression analyses carried out by Alesina et al. (2015) and Alesina and Ardagna (2012), in which percentage changes in private consumptions (with respect to GDP) are directly explained as a 
function of discretionary fiscal policies $(\triangle C A P B)$. Accordingly, parameter $j_{1}$ is meant to estimate the direct "expectation" channel through which austerity measures might influence private consumption.

(28) $g_{C}=j_{1} \Delta C A P B+j_{2} \Delta W S+\varepsilon_{i t, 5}$

Equation (28) also includes changes in the adjusted wage share $(\triangle W S)$ as an additional explanatory variable of changes in private consumption. Indeed, EAT supporters claim that well-designed fiscal packages should expressly aim to induce an internal devaluation by establishing a climate of wage moderation and by causing a sort of wage (share) suppression. Even though, on the one hand, internal devaluation and wage share suppression might stimulate growth through the "export channel", on the other hand they might jeopardize growth by squeezing domestic consumption, as stressed by the abundant literature on wage-led growth in developed countries (see Naastepad and Strom, 2006; Hein and Vogel, 2008; Stockhammer et al., 2009, among others). There is increasing empirical evidence stressing the "perverse" distributional consequences of austerity measures on the wage share and, therefore, on consumption expenditures (see Ball et al., 2013). The inclusion of $\triangle W S$ in regression (28) aims at capturing the indirect effects that restrictive fiscal policies might have on domestic private consumption by affecting functional income distribution.

The logic of equation (28) is intentionally kept quite close to its original form in the EAT literature, with the exception of the distributive term $\triangle W S$, which has been added to shed light on the alleged effectiveness of the "expectation" channel. Nonetheless, we also provide a more standard Keynesian-version of equation (28) among the range of robustness tests reported in Table A.4. In equation (28b), we include the percentage change in current households' disposable income as a third explicative variable of the dynamics of private final consumption $\left(g_{y d h}\right)$. In equation $(28 \mathrm{c})$, the percentage change in lagged households' disposable income is considered $\left(g_{y d h-l}\right)$.

Equation (29) verifies the relevance of (restrictive) discretionary fiscal policies in affecting entrepreneurs' expectations, their investment plans, and hence the growth rate of the available capital stock $\left(g_{I}\right)$.

$g_{I}=z_{1} \Delta C A P B+z_{2} i_{c r}+z_{3} g_{i}+z_{4} \Delta W S+\varepsilon_{i t, 6}$

Also in the case of private investment, the EAT-like literature adopts a quite "narrow" fiscal shockcentred specification of equation (29). In line with this literature, we check for the operativeness of the "expectation" channel by taking $\triangle C A P B$ as the first explanatory variable. Nonetheless, consistently with our theoretical specification of the investment function (see equation (11)), we extend the range of explanatory variables well beyond "pure" fiscal policy factors. On the one hand, in equation (29) we take $g_{I}$ as also depending on the lending rate on private loans $\left(i_{c r}\right)$. Indeed, this is a crucial element of the economic mechanism though which the possibly austerity-driven stabilization of financial variables might eventually affect real-side investment. On the other hand, $g_{I}$ is regressed over changes in the adjusted wage share $(\Delta W S)$, and on the growth rate of the economy $\left(g_{i}\right)$. Ceteris paribus, capital accumulation might respond positively to an increasing profit share (a declining wage share) due to a rise in investment profitability. However, a contraction in the wage share may also discourage investment via the accelerator term, by curtailing aggregate consumption and capacity utilization. Blecker (2016) has recently stressed the wage-led nature of investment demand in developed countries, at least in the medium to long run. The inclusion of 
$\triangle W S$ in equation (29) is meant to set such an empirical dispute by verifying the sensitivity of private investment to the profit share, and to the redistributive consequences of fiscal austerity in the postfinancial crisis period. The growth rate of the economy represents a proxy for the evolution of capacity utilization. Accordingly, parameter $z_{3}$ estimates the well-known "accelerator" term characterizing standard post-Keynesian investment functions.

Similarly to the case of exports, we include percentage variations (log-differences) in aggregate private consumptions and gross fixed capital formation in equations (28) and (29) as well, in order to rule out any unit root problem.

Overall, the results of our empirical exercise tell us that, from 2007 to 2016, austerity measures did not deliver the expected results. Most of the time, their effects were even contrary to the EAT's hypotheses. Such empirical evidence fully endorses our search for a more general model, in which economic expansion is just one perhaps remotely possible consequence of austerity measures amongst many other far less favourable outcomes. Table 1 shows our findings as to equations (24) (26) in more detail. In Table 1, we provide the results related to two different specifications of equations (25) and (26). The distinguishing element between equations (25) and (25b) is the inclusion in the latter of the central banks' monetary policy rate $i_{C B}$ as an additional explicative variable. In equation (26b), we take the growth rate of the rest of the world out of the set of variables describing the evolution of the real effective exchange rate.

\section{[Table 1 here]}

Our empirical evidence on the determinants of 10-year government bond yields largely confirms the validity of the theoretical assumptions encapsulated in equation (17). First, the debt-to-GDP ratio $(D / Y)$ turns out to be significant in explaining $i_{d}$ in the context of non-monetarily sovereign countries. As expected, the sign of the relationship between $(D / Y)$ and $i_{d}$ is positive. In nonmonetarily sovereign countries, the higher the debt-to-GDP ratio, the higher the yields financial investors will obtain from Eurozone governments as a compensation for an allegedly higher creditor risk. However, such a relationship turns out to be extremely weak and almost irrelevant in the context of monetarily sovereign economies (in fact, $a_{3}+a_{4}=0.0439-0.0365=0.0074$ ). In line with De Grauwe and Ji (2013), in monetarily sovereign economies financial operators seem not to consider the most common fiscal balance ratios as relevant indicators of the solidity of the public balance itself.

The same line of reasoning applies to the $C C A$. In the case of non-monetarily sovereign countries, the accumulation of a positive net investment changes their position on the international financial markets and contributes to driving down interest rates on domestic public bonds. Vice versa, net debtor economies will have to pay higher and increasing interest rates on their own public bonds. This factor may explain the widening spread between central and peripheral Eurozone countries' government bond yields in the aftermath of the 2007-2008 financial crisis. Following Merler and Pisany-Ferry (2012), yields initially shoot up in some peripheral Eurozone countries as a consequence of their exposure to capital outflows rather than of the fragility of their public accounts. The relationship between $C C A$ and $i_{d}$ remains negative even in the context of monetarily sovereign countries, however it becomes so much weaker it is negligible $\left(a_{5}+a_{6}=-0,0097\right)$. This finding strengthens the idea that public bonds issued by monetarily sovereign governments are always appealing to the eyes of financial operators, in particular when financial turbulences mount, no matter how high the debt-to-GDP ratio or the external debt may be. 
The empirical analysis of the direct effects of austerity policies on government bond yields largely supports our critique of the EAT. In non-monetarily sovereign countries, a positive rather than negative link emerges; from 2007 to 2016, austerity measures have drawn government bonds' interest rates up rather than down in (peripheral) Eurozone economies. On the one hand, these findings confirm the results by Born et al. (2014) on the initial counter-intuitive effects (with respect to EAT postulates) of austerity measures on interest rates in contexts of "fiscal stress" (which was the prevailing condition in several Eurozone countries in the aftermath of the crisis). On the other hand, our findings suggest that austerity measures could effectively trigger a perverse "financial" channel for non-monetarily sovereign countries (see figures 1 and 2). Fiscal contractions that curtail growth and increase the debt (deficit)-to-GDP ratio eventually raise rather than reduce interest rates on public bonds. In the case of monetarily sovereign countries, the relationship between $i_{d}$ and $\triangle C A P B$ becomes negative $\left(a_{1}+a_{2}=-0,1416\right)$, in line with the prediction of EAT supporters. This result seems at odds with the findings described above, according to which the relationships between $i_{d,}(D / Y)$ and $C C A$ are insignificant. A possible explanation for this apparent paradox could be found in the "risk-free" status usually attached to public bonds issued by monetarily sovereign countries, rather than the virtues of fiscal austerity per se. In the aftermath of the 2007-2008 financial crisis, all financial operators tended to reshuffle their financial positions away from "private" assets, towards public bonds issued by monetarily sovereign countries. Demand for these types of bonds increased considerably, no matter how effective the solidity of governmental finances was (De Grauwe, 2011). In this context, austerity measures widened such a "notional" excess demand for "monetarily sovereign" public bonds even further by pressing for the reduction of public deficits and reducing the supply of new government bonds. Accordingly, public bonds' yields decreased. Nonetheless, this effect is ultimately due to the natural properties of public bonds issued by governments that cannot practically go bankrupt (Kregel, 2012), rather than to the effects fiscal retrenchments might possibly have on the public budget's soundness.

Interestingly, as partial confirmation of our previous topic, it is worth stressing that the coefficient associated to the "Mario Draghi" dummy variable is significant and negative $\left(a_{7}=\right.$ 0.0209). Our empirical evidence suggests that, after 2012, Draghi's intervention has been effective in reducing pressure on the interest rates for bonds issued by peripheral Eurozone governments. This contributed significantly to the creation of a "monetary environment" more akin to the one characterizing monetarily sovereign countries, this way calming down financial speculation on peripheral countries' government bonds.

Last but not least, the level of the interest rate on government bonds is negatively affected by the overall economic growth of the economy $\left(a_{8}=-5.6389\right)$. This result reinforces the idea that economic growth, and not austerity, is the most important stabilizer of public finances.

Estimations associated to equation (25) confirm that government bond yields influence the interest rates on private loans in a significantly positive way. The latter also tend to increase in a growing economy (see the statistically positive relationship between $i_{c r}$ and $g_{i}$ ), very likely as a consequence of an increasing demand for loans. The direct effect of fiscal restrictions on $i_{c r}$ is negative, as EAT supporters would suggest. Two points are worth stressing about this. The first is that the distinction between non-monetarily sovereign and monetarily sovereign economies seems to be statistically irrelevant as far as $i_{c r}$ is concerned (see the statistically insignificant dummy variable $\triangle C A P B_{M S}$ in equations (25) and (25b)). The second and most relevant point is that the direct effect of austerity measures is considerably downsized when we introduce $i_{C B}$ as an additional explicative variable in equation (25b). Indeed, $i_{C B}$ displays a strong and positive effect on $i_{c r}$ (i.e. the more expansionary the monetary policy, the lower the lending rate on loans to the private sector 
becomes). Simultaneously, the coefficient linked to discretionary fiscal policy shrinks from -0.2379 in equation (25) to -0.0769 in equation (25b). Accordingly, while the direct effect of an improvement in the CAPB on $i_{c r}$ remains slightly negative, its overall effect (if we also include the indirect effect that changes in the $C A P B$ might cause on $i_{c r}$ via $i_{d}$ ) turns out to be small and positive in the case of non-monetarily sovereign economies $\frac{d i_{c r}}{d \triangle C A P B}=\left[\frac{\partial i_{c r}}{\partial \triangle C A P B}+\frac{\partial i_{c r}}{\partial i_{d}} \frac{\partial i_{d}}{\partial \triangle C A P B}\right]=-0.0769+$ $0.2818 * 0.3634=0.026$.

The explicative power of the equations (26) and (26b) is very limited ${ }^{9}$. Austerity measures seem to have no statistically relevant effect on the real exchange rate $(q)$, differently from what the advocates of EAT and, more generally, most open-economy mainstream models would expect. What is more is that this effect does not have the expected sign. Fiscal austerity seems to cause an appreciation rather than a devaluation of the real exchange rate (i.e. an increase of $1 / q$, and a reduction of $q$ ). At the end of the day, the central bank policy rate $i_{C B}$ is the only significant explicative variable entering equation (26b) with the expected positive sign.

Table 2 gives a detailed description of the effects austerity policies have had on the main components of GDP from 2007 to 2016. In the post-financial crisis period, austerity measures do not play any direct and statistically relevant role in determining the dynamics of private consumption and export flows. Any possible direct effect would still be negative and therefore contrary to the expectations of EAT supporters. In the case of exports, this direct negative effect (although insignificant) is magnified by the perverse indirect effect of the appreciation of the real exchange rate. Actually, $q$ is the only significant variable affecting export dynamics with the expected negative sign. As expected, private consumption responds positively to increases in the wage share. The robustness tests reported in table A.4 (see equations (28b) and (28c)) confirm these findings. Since 2007, austerity measures have not been statistically significant to explain the dynamics of private consumption. The "expectation" channel appears to be inoperative, to say the least. On the contrary, the adjusted wage share has a positive and significant impact on households' final consumption, even after households' disposable income is included in the regression. In line with the Keynesian theory, growth in current (see equation (28b)) or lagged (see equation (28c)) disposable income has a positive effect on households' consumption. In the end, consistently with Ball et al. (2013), any austerity policy that aims at cutting public transfers to households, and at downsizing the wage share by establishing a climate of wage moderation, will probably reduce consumption expenditures and have contractionary effects, rather than support recovery.

Evidence of austerity's effects on private investments is slightly more controversial. First, austerity measures seem to play a very limited positive direct effect $\left(z_{1}=0.0086\right)$ on private investments. Notwithstanding this, in the case of non-monetarily sovereign countries, fiscal austerity can eventually curtail rather than stimulate private investments through three additional pernicious "indirect" channels: (1) the increase in the lending rate $i_{c r}$ on loans to the private sector (which has, as expected, a significantly negative effect on private investments $z_{2}=-0.0240$ ); (2) the possible slowdown in overall economic growth, which influences investment positively through the accelerator $\left(z_{3}=2.5334\right)$; (3) the reduction through time of the wage share, given the apparently wage-led nature of investment decisions in the economies under observation in the last decade (i.e. $\left.z_{4}=0.0104\right)$. In the case of monetarily sovereign countries, the fact that austerity policies may contribute to reducing interest rates on private loans (via their effect on $i_{d}$ ) might surely help revive private investments. Yet, the concerns about the indirect contractionary effects austerity might trigger by hampering overall growth dynamics and by downsizing the wage share are still valid. These concerns go hand-in-hand with our previous emphasis on the fact that austerity measures are, 
in general, hardly effective by themselves (see the evidence on non-monetarily sovereign countries). Indeed, it seems to be far more important to create a safer "monetary environment", which could stabilize public finances and make government bonds "risk-free" by default.

\section{Conclusions}

In this paper, we develop a comprehensive critique of expansionary austerity theory (EAT). Our critique is moved from both the theoretical and empirical terrains.

We first present a short-run model, playing on EAT's same grounds by incorporating some of its crucial assumptions and mechanisms, and by carefully formalizing the components of a supposedly well-designed austerity package.

Even admitting these EAT-like features in the model, austerity-led short-run expansions still remain highly uncertain events that could theoretically take place only under unrealistic circumstances (such as an expanding private consumption taking place despite permanent cuts in public transfers in the present and uncertain tax reductions in the future).

In the second part of the paper, we test the empirical solidity of EAT's building blocks econometrically. Table 3 summarizes the comparison between the main outcomes of EAT, the wider range of results our theoretical model allows for, and the empirical findings of our econometric analysis.

[Table 3 here]

Our empirical evidence reinforces our theoretical doubts. The inclusion of explicative variables capturing the "institutional monetary framework" in which fiscal policy is implemented contributes to explain why our results significantly diverge from those put forward by EAT supporters. Also, the time horizon of our analysis, i.e. the post-financial crisis period, suggests that EAT expectation channel may well be ineffective in a context of widespread economic pessimism and depressed animal spirits. Since 2007, austerity did not succeed in stabilizing public finances in non-monetarily sovereign countries. Rather, it may have triggered a perverse "financial" channel, in which hiking interest rates have reinforced widening public balance disarrays. In monetarily sovereign countries, the "safe haven" status traditionally attached to their own public bonds in times of financial turmoil might have been far more important than austerity per se in making public finances solid. Furthermore, the "external" and "expectation" channels seem either not to have been operative, or to have operated in the opposite direction with respect to what EAT supporters expected.

In the end, our analysis suggests that EAT policy prescriptions should be taken as purely theoretical speculations that rely on unrealistic assumptions and lack strong empirical grounds. Our findings suggest that EAT cannot provide any solid guideline for the conduction of fiscal policies aimed at obtaining positive society-wide objectives, at least in the wake of the most dramatic financial-led recession of the post-World War II period. 


\section{Endnotes}

1. See Sutherland (1997) for cases of possible non-Keynesian effects of expansionary fiscal measures when undertaken in a context of high public debt. Perotti (2013) stresses that fiscal contractions may be expansionary in the presence of high interest rates, in particular when they contribute to reducing risk premiums on financial assets (government bonds first of all) and prompt a considerable reduction in nominal interest rates.

2. Alesina and Ardagna (2010) argue that a lower public sector employment rate, lower public sector wages, and (or) lower degrees of labour market protection (such as cuts in unemployment benefits), tend to increase the individual labour supply and reduce trade unions' bargaining power. It is easy to see how these effects of fiscal adjustments may stimulate growth in supply-side mainstream models.

3. The same logic may apply in the case of a reduction of public benefits to unemployed people that could lower average expected income.

4. Indeed, assuming that $i_{d}$ positively depended on public debt-to-GDP ratio, rather than (or along with) the deficit-toGDP ratio, would not have changed the logic of the model. On the contrary, it would have made the model even more sensitive to any austerity-led contraction in economic activity (hence increase in the debt-to-GDP ratio); the perverse consequences of austerity packages would have emerged even more easily.

5. De Grauwe and Ji (2013) explicitly state that " [in the case of "stand-alone" economies] financial markets do not seem to be concerned with the size of the government debt and of the fiscal space [...] despite the fact that the variation of these ratios is of a similar order of magnitude as the one observed in the Eurozone (De Grauwe and Ji, 2013, p. 24)".

6. Ali Abbas et al. (2013) note that "front-loaded consolidations have tended to increase public debt in the short run [...] Empirically, fiscal effort has been more likely to reduce public debt when growth has been stronger [whilst] the debt-to-GDP ratio increases in the short run when fiscal consolidations come at the cost of lower economic activity. [In the end] while credibility effects can ease the pain of fiscal adjustment through lower risk premiums, this is unlikely to fully offset the short-run adverse impact on economic activity (Ali Abbas et al., 2013, p. 3)”.

7. The fixed effect multivariate econometric technique used in this section of the paper allows us to extend the time horizon of our analysis to the years $(2007$ - 2009) that have been most affected by the "disturbances" associated to the last financial crisis. This was not possible in the case of the very basic simple correlation analyses portrayed in Figures $3-5$, since that they could not properly account for the distortionary effects of the financial shock itself.

8. In regression (26), we use $(1 / q)$ rather than $q$ as the dependent variable to be consistent with IMF data on the real effective exchange rate (REER), which is computed as the inverse of the theoretical formulation we adopt in equation (7). Accordingly, a depreciation (appreciation) of real exchange rate, i.e. a reduction (increase) in IMF's REER, corresponds to a decreasing (increasing) $1 / q$ ratio (i.e. an increase (reduction) in $q$ ).

9. The goodness-of-fit measures of the various econometric specifications we adopt are not very large. This is partially due to the inclusion in our dataset of the years in the immediate aftermath of the worldwide financial crisis, in which the variability in the main macroeconomic variables was considerable. As stressed in the main text, the within- $R^{2}$ assesses the effectiveness of our model in explaining the relationships between the variability of dependent and explanatory variables. We believe that the within- $R^{2}$ associated to our regressions is reasonably high if we take into account the high variability characterizing our time spell.

\section{References}

Alesina, A. "Fiscal adjustments: lessons from recent history", paper prepared for the EU Ecofin meeting in Madrid, April 15th 2010.

Alesina, A., and Perotti, R. "Fiscal Adjustments in OECD Countries: Composition and Macroeconomic Effects", IMF Staff Papers, 1997, 44 (2), 210 - 248.

Alesina A., and Ardagna, S. "Large Changes in Fiscal Policy: Tax versus Spending", in J.R. Brown. ed. Tax Policy and the Economy, 2010, 35 - 68. 
Alesina, A., and Ardagna, S. “The Design of Fiscal Adjustments", NBER Working Paper n. 18423, 2012.

Alesina, A., Favero, C., and Giavazzi, F. "The Output Effects of Fiscal Consolidation Plans", Journal of International Economics, 2015, 96 (supplement 1), S19 - S42.

Ali Abbas, A., Akitoby, B., Andritzki, J., Berger, H., Komatsuzaki, T., and Taylor, J. "Dealing with High Debt in a Era of Low Growth", IMF Staff Discussion Note 13/07, 2013.

Auerbach, A., and Gorodnichenko, Y. "Measuring the Output Responses to Fiscal Policy", American Economic Journal: Economic Policy, 2012, 4 (2), 1 - 27.

Baker, D., and Rosnick, D. "Stimulus and fiscal consolidation: The evidence and implications", IMK Working Paper n. 135, 2014.

Ball, L., Furceri, D., Leigh, D., and Loungani, P. "The distributional effects of fiscal consolidation", IMF Working Paper n. 13/151, 2013.

Bhaduri, A., and Marglin, S. "Unemployment and the Real Wage: The Economic Basis for Contesting Political Ideology", Cambridge Journal of Economics, 1990, 4 (4), 375 - 393.

Blecker, R. A. "Wage-led versus profit-led demand regimes: the long and the short of it", Review of Keynesian economics, 2016, 4 (4), 373 - 390.

Boyer, R. "The four fallacies of contemporary austerity policies: the lost Keynesian legacy", Cambridge Journal of Economics, 1992, 36 (1), 283- 312.

Born, B., Muller, G.J., and Pfeifer, J. "Does austerity pay off?”, SAFE working paper series n.77, 2014.

De Grauwe, P. "Managing a Fragile Eurozone”, Cesifo Forum, 2011, n. 2/2011, 40 - 45.

De Grauwe, P., and Ji, Y. "Self-fulfilling Crises in the Eurozone: An Empirical Test", Journal of International Money and Finance, 2013, 34 (April), 15 - 36.

Foresti, P., and Marani, U. "Expansionary fiscal consolidations: Theoretical underpinnings and their implications for the eurozone", Contributions to Political Economy, 2014, 33 (1), 19 - 33.

Giavazzi, F., and Pagano, M. "Can Severe Fiscal Contractions Be Expansionary?Tales of two Small European Countries", NBER Macroeconomic Annual, 1990, 5, 75 - 122.

Giavazzi, F., and Pagano, M. "Non-Keynesian Effects of Fiscal Policy Changes: International Evidence and the Swedish Experience", Swedish Economic Policy review, 1996, 39 (3), 635 657.

Giavazzi, F., Jappelli, T., and Pagano, M. "Searching for non-monotonic effects of fiscal policy: New evidence”, Monetary and Economic Studies, 2005, 23 (S1), 197 - 217.

Guajardo, J., Leigh D., and Pescatori, A. "Expansionary Austerity: New Empirical Evidence", IMF Working Paper n. 158, 2011.

Hein, E., Vogel, L. "Distribution and growth reconsidered: empirical results for six OECD countries”, Cambridge Journal of Economics, 32 (3), 479 - 511.

Kregel, J., "Six Lessons from the Euro Crisis", Levy Economics Institute of Bard College Policy Note n. 2012/10, 2012.

Lavoie, M. Post-Keynesian Economics: New Foundations, Cheltenham (UK) and Northampton (USA): Edward Elgar, 2015.

Mehrling, P. The New Lombard Street. How the Fed Became a Dealer of Last Resort. Princeton, NJ: Princeton University Press, 2011.

Merler, S., and Pisani-Ferry, J. "Sudden Stops in the euro area", Review of Economics and Institutions, 2012, 3 (3), $1-23$.

Micossi, S. "The Monetary Policy of the European Central Bank (2002 - 2015)", CEPS Special Report n. 109. 
Naastepad, C.W., and Storm, S. "OECD demand regimes (1960-2000)", Journal of Post Keynesian Economics, 2006, 29 (2), 211 - 246.

Palley, T. "The Simple Macroeconomics of Fiscal Austerity", Public Sector Debt and Deflation, IMK Working Paper n. 8/2010, 2010.

Perotti, R. The "Austerity Myth": Gain without Pain?, in Alesina, A., and Giavazzi, F. eds. Fiscal Policy after the Financial Crisis, University of Chicago Press, 2013, 307 - 354.

Qazizada, W., and Stockhammer, E. "Government spending multipliers in contractions and expansions", International Review of Applied Economics, 2015, 29 (2), 238 - 258.

Stockhammer, E., Onaran, O., and Ederer, S. "Functional income distribution and aggregate demand in the Euro area", Cambridge Journal of Economics, 2009, 33 (1), 139 - 159.

Sutherland, A. "Fiscal Crises and Aggregate Demand: Can High Public Debt Reverse the Effect of Fiscal Policy?", Journal of Public Economics, 1997, 65 (2), 147 - 162.

Taylor, L. Income Distribution, Inflation and Growth: Lectures on Structuralist Macroeconomic Theory, MIT Press: Cambridge (USA) and London (UK), 1991, 143 - 150. 


\section{Figures and Tables}

Figure 1 - Austerity-led economic contraction and rising deficit-to-GDP ratios.

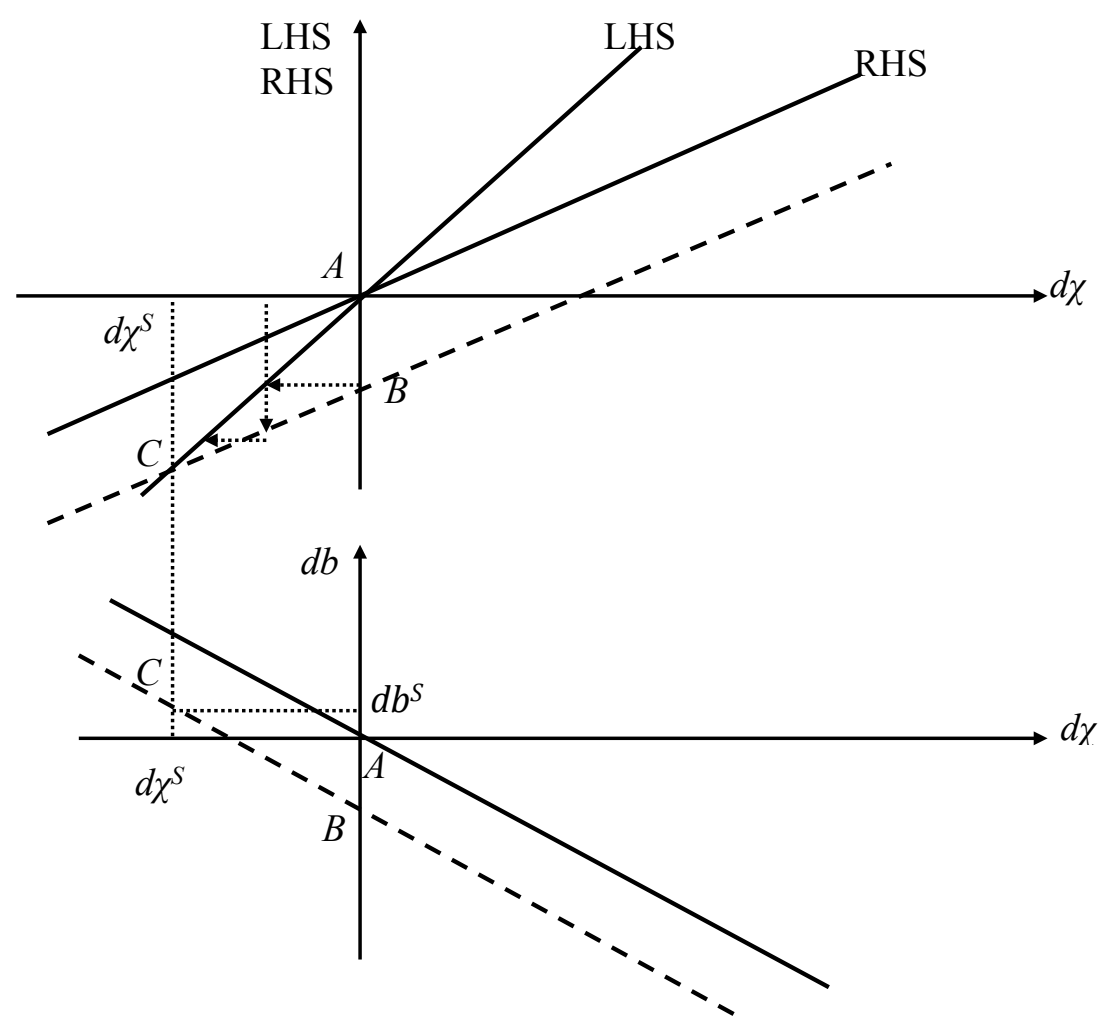

Figure 2 - Austerity-led "endless" economic contraction and explosive deficit-to-GDP (and debt-toGDP) ratios in an unstable short-run setting.

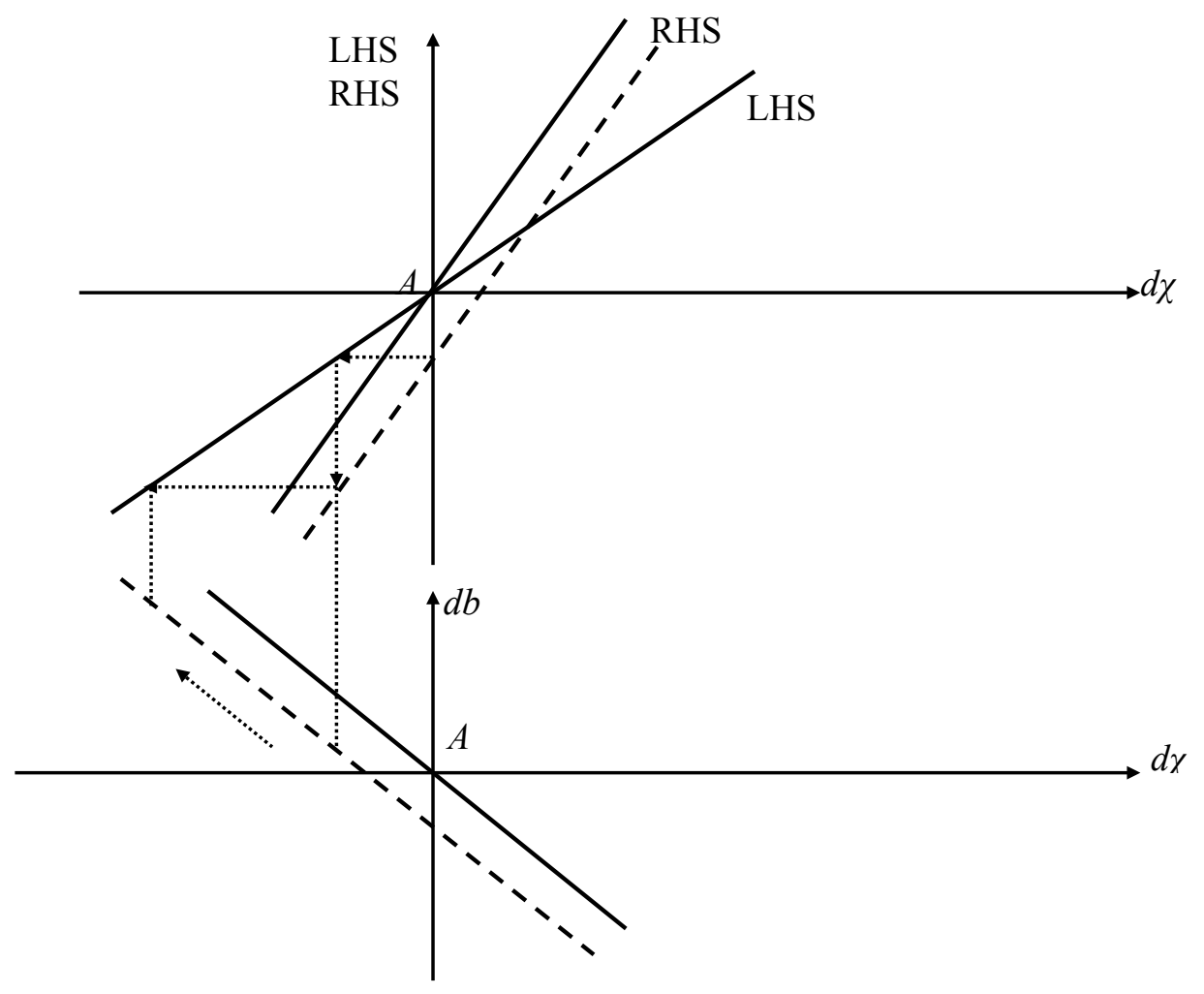


Figure 3 - Correlation between annual change in CAPB and GDP growth, 2010 - 2016.

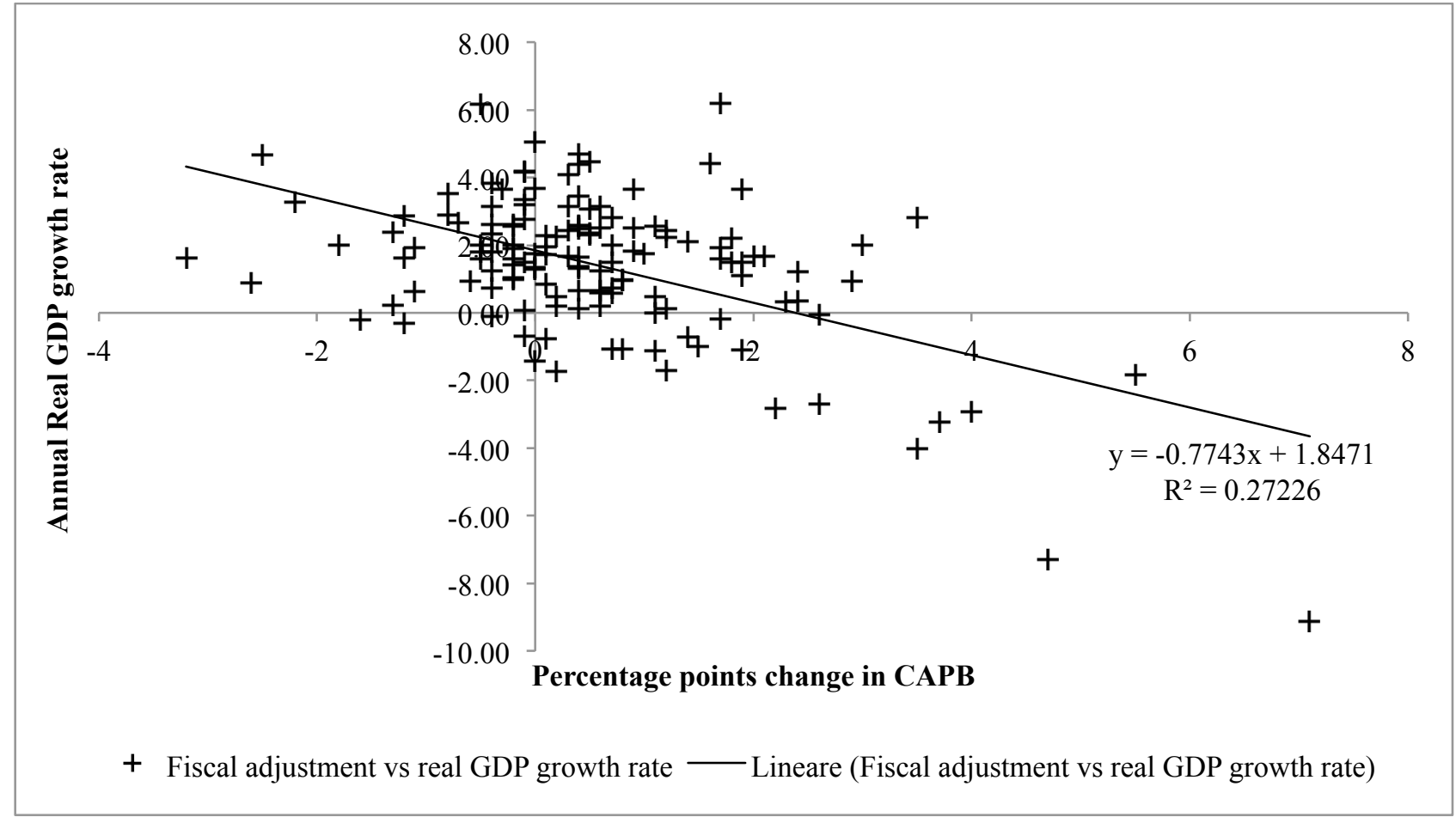

Source: authors' computations on data from AMECO and IMF fiscal monitor

Figure 4 - Correlation between annual change in CAPB and households' private consumption growth rate, $2010-2016$.

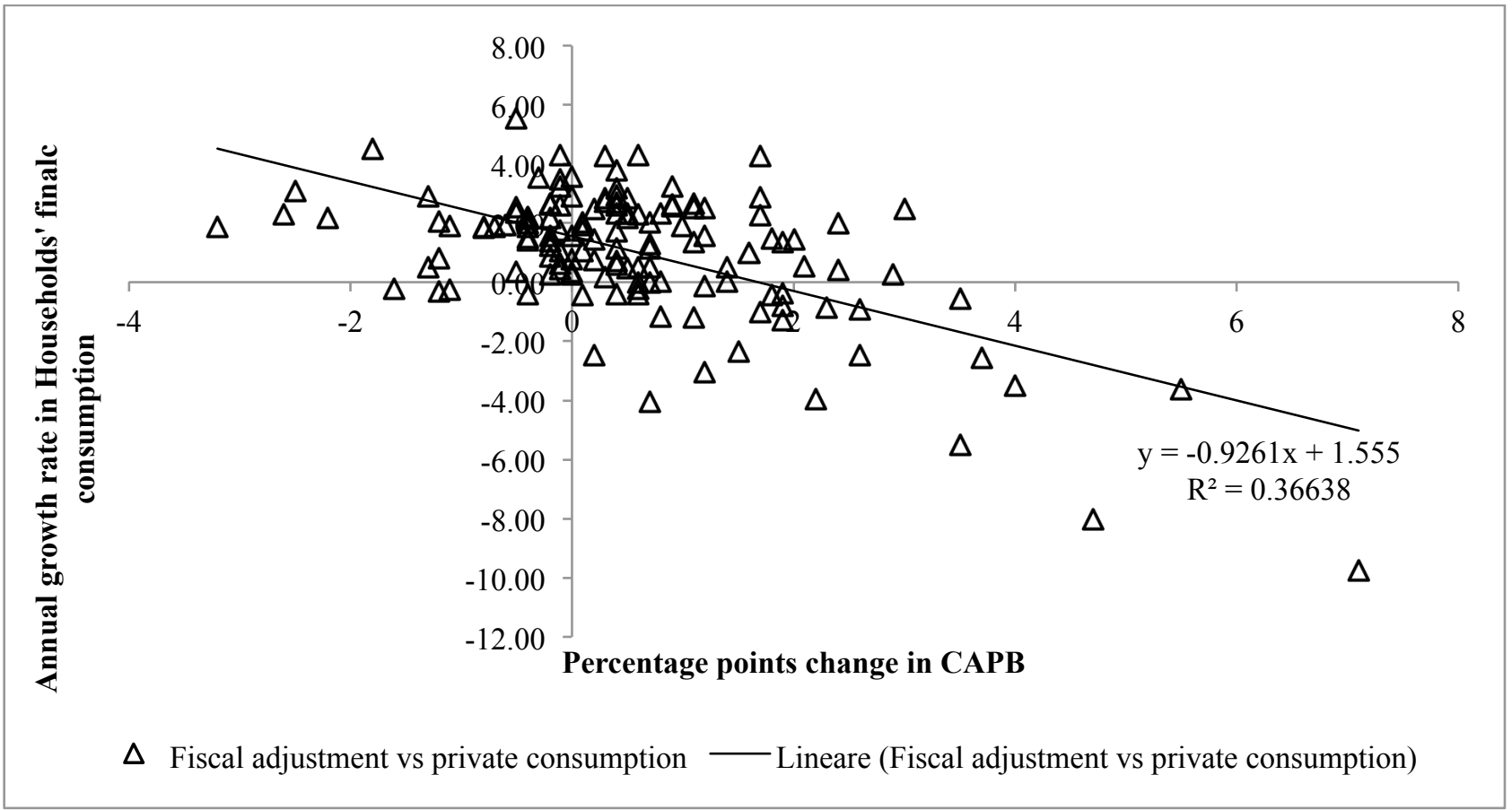

Source: authors' computations on data from AMECO and IMF fiscal monitor 
Figure 5 - Correlation between annual change in CAPB and private gross fixed capital formation growth rate, $2010-2016$.

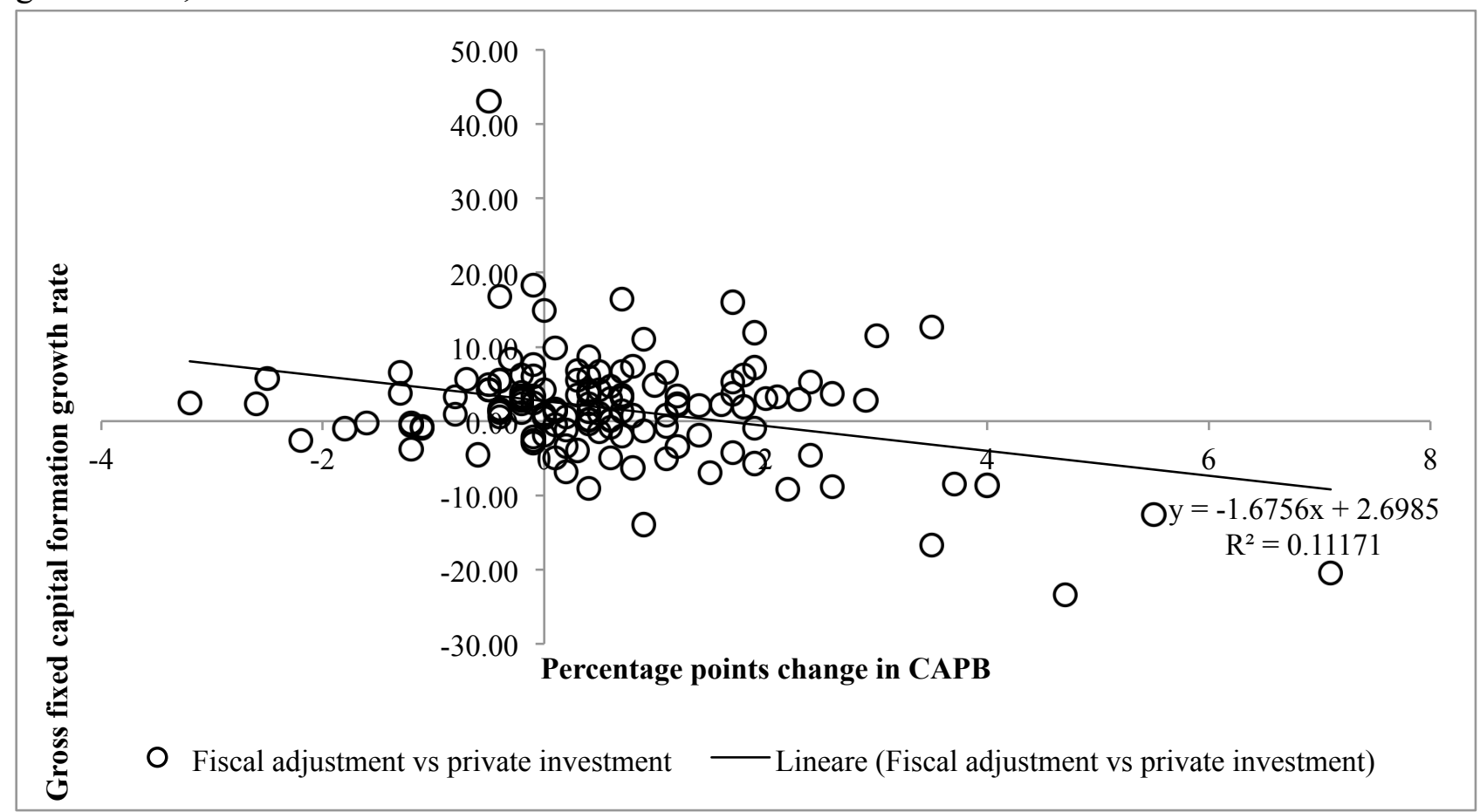

Source: authors' computations on data from AMECO and IMF fiscal monitor 
Table 1 - Estimation results for interest rates and the real exchange rates, 2007 - 2016.

\begin{tabular}{|c|c|c|c|c|c|}
\hline \multirow[b]{2}{*}{ Variables } & \multicolumn{4}{|c|}{ Dependent Variable } & \multirow[b]{2}{*}{$1 / q(26 \mathrm{~b})$} \\
\hline & $i_{d}(24)$ & $i_{c r}(25)$ & $i_{c r}(25 b)$ & $1 / q(26)$ & \\
\hline$\triangle C A P B$ & $\begin{array}{c}0.3634 * * * \\
(0.1017)\end{array}$ & $\begin{array}{c}-0.2379 * * * \\
(0.1272)\end{array}$ & $\begin{array}{c}-0.0768 * * * \\
(0.0269)\end{array}$ & $\begin{array}{l}0.4994 * \\
(0.2726)\end{array}$ & $\begin{array}{c}0.4154 \\
(0.2852)\end{array}$ \\
\hline$\triangle C A P B_{M S}$ & $\begin{array}{c}-0.5050 * * * \\
(0.1235)\end{array}$ & $\begin{array}{l}-0.2133 \\
(0.2609)\end{array}$ & $\begin{array}{l}-0.3405 \\
(0.2658)\end{array}$ & & \\
\hline$g_{i}$ & $\begin{array}{l}-5.6389 * \\
(3.0776)\end{array}$ & $\begin{array}{l}5.5091 * * * \\
(1.8025)\end{array}$ & $\begin{array}{r}3.2727 * * \\
(1.4823)\end{array}$ & & \\
\hline$\frac{D}{Y}$ & $\begin{array}{c}0.0439 * * * \\
(0.0065)\end{array}$ & & & & \\
\hline$\left(\frac{D}{Y}\right)_{M S}$ & $\begin{array}{c}-0.0365^{* *} \\
(0.0177)\end{array}$ & & & & \\
\hline$\left(\frac{D}{Y}\right)_{M D R A G H I}$ & $\begin{array}{c}-0.0209 * * * \\
(0.0052)\end{array}$ & & & & \\
\hline$C C A$ & $\begin{array}{l}-0.0500^{*} \\
(0.0269)\end{array}$ & & & $\begin{array}{c}0.0329 \\
(0.0652)\end{array}$ & $\begin{array}{c}0.0339 \\
(0.0666)\end{array}$ \\
\hline$C C A_{M S}$ & $\begin{array}{l}0.0403 * \\
(0.0231)\end{array}$ & & & $\begin{array}{c}0.0483 \\
(0.1309)\end{array}$ & $\begin{array}{c}0.1165 \\
(0.1370)\end{array}$ \\
\hline$i_{d}$ & & $\begin{array}{c}0.3541 * * * \\
(0.1272)\end{array}$ & $\begin{array}{c}0.2818 * * * \\
(0.0625)\end{array}$ & & \\
\hline$i_{C B}$ & & & $\begin{array}{l}0.4421 * * * \\
(0.1038)\end{array}$ & $\begin{array}{c}1.9354 * * * \\
(0.5224)\end{array}$ & $\begin{array}{c}1.7494 * * * \\
(0.5594)\end{array}$ \\
\hline$g_{R W}$ & & & & $\begin{array}{l}-0.1585 \\
(0.986)\end{array}$ & \\
\hline Time dummies & Yes & No & No & No & No \\
\hline Within $-R^{2}$ & 0.6620 & 0.3987 & 0.4917 & 0.2474 & 0.1742 \\
\hline Number of observations & 216 & 216 & 216 & 211 & 211 \\
\hline $\begin{array}{l}\text { Wald test for } a_{1}+ \\
a_{2}=0(p-\text { value })\end{array}$ & 0.0026 & & & & \\
\hline $\begin{array}{l}\text { Wald test for } a_{3}+a_{4} \\
=0(p-\text { value })\end{array}$ & 0.0032 & & & & \\
\hline $\begin{array}{l}\text { Wald test for } a_{5}+ \\
a_{6}=0(p-\text { value })\end{array}$ & 0.1277 & & & & \\
\hline $\begin{array}{l}\text { Wald test for } b_{2}+b_{3} \\
=0(p-\text { value })\end{array}$ & & 0.0000 & 0.0001 & & \\
\hline $\begin{array}{l}\text { Wald test for } \beta_{3}+ \\
\beta_{3.1}=0(p-\text { value })\end{array}$ & & & & & \\
\hline $\begin{array}{l}\text { Wald test for } c_{2}+c_{3}= \\
0(p-\text { value })\end{array}$ & & & & 0.2216 & 0.2272 \\
\hline
\end{tabular}

Clustered at country level and robust standard errors are shown in brackets. ${ }^{*} \mathrm{p}<0.1,{ }^{* *} \mathrm{p}<0.05,{ }^{* * *} \mathrm{p}<0.01$. The coefficients for year dummies are not reported.

Note: in equations (25b), (26), and (26b), $i_{C B}$ is not available for Japan and Iceland. We used the money market interest rate as a proxy. We tested the robustness of our results by excluding these two countries from our sample in regressions (25c) and (26c) - see Table A.4 in the Appendix.

We checked and confirmed the robustness of our results in estimations (26) and (26b) by dropping the insignificant effect of CCA - see Table A.4 in the Appendix.

In equations (26) and (26b), Slovenia was excluded from these estimations since the real effective exchange rate for its currency was not available. 
Table 2 - Estimation results for main GDP components other than public consumption and imports, 2007-2016

\begin{tabular}{|c|c|c|c|}
\hline \multirow[b]{2}{*}{ Variables } & \multicolumn{3}{|c|}{ Dependent Variable } \\
\hline & $g_{E}(27)$ & $g_{C}(28)$ & $g_{I}(29)$ \\
\hline$\triangle C A P B$ & $\begin{array}{r}-0.0036 \\
(.0026)\end{array}$ & $\begin{array}{l}-0.0006 \\
(0.0008)\end{array}$ & $\begin{array}{c}0.0086^{* *} \\
(0.0031)\end{array}$ \\
\hline$g_{q}$ & $\begin{array}{c}-0.4131 * * \\
(0.1841)\end{array}$ & & \\
\hline$g_{R W}$ & $\begin{array}{l}-.15323 \\
(1.172)\end{array}$ & & \\
\hline$i_{c r}$ & & & $\begin{array}{c}-0.0211^{* * *} * \\
(0.0055)\end{array}$ \\
\hline$g_{i}$ & & & $\begin{array}{c}2.5334 * * * \\
(0.1756)\end{array}$ \\
\hline$\Delta W S$ & & $\begin{array}{c}0.0104 * * * \\
(0.0023)\end{array}$ & $\begin{array}{c}0.0169 * * * \\
(0.0047)\end{array}$ \\
\hline Time dummies & Yes & No & No \\
\hline Within $-R^{2}$ & 0.7067 & 0.5304 & 0.6496 \\
\hline Number of observations & 216 & 216 & 216 \\
\hline
\end{tabular}

Clustered at country level and robust standard errors are shown in brackets. ${ }^{*} \mathrm{p}<0.1,{ }^{* *} \mathrm{p}<0.05,{ }^{* * *} \mathrm{p}<0.01$. The coefficients for year dummies are not reported.

Note: Equation (27b) checks and confirms the robustness of our estimations in equation (27) by excluding the insignificant effect of the growth rate of GDP of the rest of the world out of the picture.

Table 3 - Summative comparison between the EAT hypothesis, our theoretical model, and the connected econometric analysis

\begin{tabular}{|c|c|c|c|c|c|c|}
\hline Standpoint & $\frac{\partial i_{d}}{\partial \Delta C A P B}$ & $\frac{d i_{c r}}{d \triangle C A P B}$ & $\frac{\partial(1 / q)}{\partial \Delta C A P B}$ & $\frac{d I}{d \triangle C A P B}$ & $\frac{\partial C}{\partial \triangle C A P B}$ & $\frac{\partial E}{\partial \triangle C A P B}=\frac{\partial E}{\partial(1 / q)} \frac{\partial(1 / q)}{\partial \Delta C A P B}$ \\
\hline$E A T$ & $<0$ & $<0$ & $<0$ & $>0$ & $>0$ & $>0$ \\
\hline Our theoretical model & $\lesseqgtr 0$ & $\lesseqgtr 0$ & $<0$ & $\lesseqgtr 0$ & $\lesseqgtr 0$ & $>0$ \\
\hline $\begin{array}{c}\text { Estimated effect } \\
\text { non - MS countries } \\
(2007-2016)\end{array}$ & $>0$ & $>0$ & insign., $>0$ & $\lesseqgtr 0$ & insign.,$<0$ & insign.,$<0$ \\
\hline $\begin{array}{c}\text { Estimated effect } \\
\text { MS countries } \\
(2007-2016)\end{array}$ & $<0$ & $<0$ & insign., $>0$ & $\lesseqgtr 0$ & insign.,$<0$ & insign.,$<0$ \\
\hline
\end{tabular}




\section{Appendix}

Table A.1 Variable definitions, sources and composition of the sample

\begin{tabular}{|c|c|c|}
\hline Variable & $\begin{array}{ll}\text { Definition } \\
\end{array}$ & Source \\
\hline$i_{d}$ & Long-term interest rate on 10 -year government bonds & $\mathrm{AMECO}+\mathrm{OECD}$ \\
\hline$i_{c r}$ & Lending interest rate on loans to the private sector & IMF Financial Statistics + ECB statistics \\
\hline$i_{C B}$ & Central bank policy rate* & IMF financial statistics \\
\hline$q$ & Real effective exchange rate & IMF financial statistics \\
\hline C & Private consumption expenditures at current prices & AMECO \\
\hline$I$ & Gross fixed capital formation at current prices & AMECO \\
\hline E & Export of goods and services at current prices & AMECO \\
\hline$Y_{i}$ & Gross Domestic Product at current prices & AMECO \\
\hline$Y_{R W}$ & Rest of the World Product at current prices & $Y_{w}-Y_{i}$ \\
\hline$W S$ & Adjusted wage share & AMECO \\
\hline$C A P B$ & Cyclically Adjusted Primary Balance & IMF Fiscal Monitor \\
\hline$D / Y$ & Debt-to-GDP ratio & IMF World Economic Outlook \\
\hline$C C A$ & Cumulative current account 2007-2016 & IMF World Economic Outlook \\
\hline$Y_{d h}$ & Households' disposable income & OECD \\
\hline \multicolumn{3}{|c|}{ Sample composition } \\
\hline $\begin{array}{l}\text { Non-monetarily } \\
\text { sovereign } \\
\text { countries }\end{array}$ & $\begin{array}{l}\text { Austria, Belgium, Cyprus, Finland, France, Germany, Greece, } \\
\text { Ireland, Italy, Luxemburg, Malta, Netherlands, Portugal, Slovakia, } \\
\text { Slovenia, Spain }\end{array}$ & \\
\hline $\begin{array}{l}\text { Monetarily } \\
\text { sovereign } \\
\text { countries (MS) }\end{array}$ & $\begin{array}{l}\text { Australia, Canada, Denmark, Iceland, Japan, South Korea, Norway, } \\
\text { New Zealand, Sweden, Switzerland, UK, USA }\end{array}$ & \\
\hline
\end{tabular}

Table A.2 - Unit root tests ( $H_{0}$ hypothesis: panel contains unit root)

Variable Fisher test $(p-$ value $) \quad$ LLC test $(p-$ value $)$

\begin{tabular}{cll}
\hline$i_{d}$ & 0.0260 & $0.000^{*}$ \\
$i_{c r}$ & 0.0000 & 0.0000 \\
$\frac{D}{Y}$ & 0.0000 & 0.0000 \\
$C C A$ & 0.2350 & 0.0640 \\
$g_{i}$ & 0.0000 & 0.0000 \\
$g_{R W}$ & 0.0000 & 0.0000 \\
$\Delta C A P B$ & 0.0000 & 0.0000 \\
$i_{C B}$ & 0.0000 & 0.0000 \\
$q$ & 0.0000 & 0.0000 \\
$g_{q}$ & 0.0000 & 0.0000 \\
$g_{I}$ & 0.0000 & 0.0000 \\
$g_{C}$ & 0.0000 & 0.0000 \\
$g_{E}$ & 0.0000 & 0.0000 \\
\hline
\end{tabular}


Table A.3 - Pesaran test for cross-sectional independence

\begin{tabular}{ccc}
\hline Specification & $\begin{array}{c}p-\text { value } \\
\text { without time dummies }\end{array}$ & $\begin{array}{c}p-\text { value } \\
\text { with time dummies }\end{array}$ \\
\hline$(24)$ & 0.0001 & 0.9943 \\
$(25)$ & 1.0000 & \\
$(25 \mathrm{~b})$ & 0.9932 & \\
$(26)$ & 1.0000 & \\
$(26 \mathrm{~b})$ & 1.0000 & \\
$(27)$ & 0.9882 & \\
$(28)$ & 1.0000 & 0.9566 \\
\hline
\end{tabular}

Table A.4 - Estimation results for robustness tests, 2007-2016.

\begin{tabular}{|c|c|c|c|c|c|}
\hline \multirow[b]{2}{*}{ Variables } & \multicolumn{5}{|c|}{ Dependent Variable } \\
\hline & $i_{c r}(25 c)$ & $1 / q(26 c)$ & $g_{E}(27 b)$ & $g_{c}(28 b)$ & $g_{c}(28 c)$ \\
\hline$\triangle C A P B$ & $\begin{array}{c}-0.0729 * * \\
(0.0254)\end{array}$ & $\begin{array}{c}0.4237 \\
(0.2658)\end{array}$ & $\begin{array}{l}-0.0022 \\
(0.0028)\end{array}$ & $\begin{array}{l}-0.0004 \\
(0.0009)\end{array}$ & $\begin{array}{c}0.0008 \\
(0.0010)\end{array}$ \\
\hline$\triangle C A P B_{M S}$ & $\begin{array}{c}0.0297 \\
(0.04346)\end{array}$ & & & & \\
\hline$g_{i}$ & $\begin{array}{l}1.4929 \\
(1.634)\end{array}$ & & & & \\
\hline$g_{R W}$ & & $\begin{array}{l}-0.5204 \\
(8.056)\end{array}$ & & & \\
\hline$i_{d}$ & $\begin{array}{c}0.2480 * * * \\
(0.0519)\end{array}$ & & & & \\
\hline$i_{C B}$ & $\begin{array}{c}0.4219 * * * \\
(0.1026)\end{array}$ & $\begin{array}{c}1.8378 * * * \\
(0.4540)\end{array}$ & & & \\
\hline$g_{q}$ & & & $\begin{array}{c}-0.5211 * * * \\
(0.1155)\end{array}$ & & \\
\hline$\triangle A W S$ & & & & $\begin{array}{c}0.0100 * * * \\
(0.000)\end{array}$ & $\begin{array}{c}0.0101 * * * \\
(0.0023)\end{array}$ \\
\hline$g_{y d h}$ & & & & $\begin{array}{l}0.0743 * \\
(0.0430)\end{array}$ & \\
\hline$g_{y d h-1}$ & & & & & $\begin{array}{c}0.1305^{* *} * \\
(0.0616)\end{array}$ \\
\hline Time dummies & No & No & Yes & No & No \\
\hline Within $-R^{2}$ & 0.5562 & 0.2720 & 0.7262 & 0.5143 & 0.5044 \\
\hline Number of observations & 190 & 190 & 216 & 216 & 216 \\
\hline
\end{tabular}


